\title{
Chapter 10 \\ Teaching for Diversity with UDL: Analysing Teacher Competence
}

\author{
Suvi Lakkala (D) and Outi Kyrö-Ämmälä
}

\begin{abstract}
This chapter is a description of collaborative action research on teacher competence in the context of inclusive education and universal design for learning (UDL). Our goal was to analyse what kinds of professional competencies teachers need when they are implementing UDL in heterogeneous classes. The action research was carried out as a case study together with two co-teachers and a class teacher, who implemented UDL in their heterogeneous classes. As a theoretical framework for teacher competence, we used the multidimensional adapted process (MAP) model of teaching, developed by Finnish researchers and teacher educators. We identified several teacher skills that are needed when the UDL approach is applied. According to our results, the most overarching necessary competence was the teachers' cognitive skills. Applying UDL required the ability to flexibly transform one's own teaching and learning situations. Furthermore, the teachers' social skills appeared as an important attribute as their pupils were highly heterogeneous with diverse needs, and the teachers needed to collaborate with many other professionals and parents. Also, each teacher's personal orientation, such as values, beliefs and ethics, played a crucial role in UDL while the teachers shared a common set of values, striving towards inclusive education.
\end{abstract}

Keywords Action research · Inclusive education - UDL · Teacher competence · Teacher's values · Teacher's skills

S. Lakkala $(\bowtie) \cdot$ O. Kyrö-Ämmälä

University of Lapland, Rovaniemi, Finland

e-mail: suvi.lakkala@ulapland.fi; outi.kyro-ammala@ulapland.fi 


\subsection{Introduction}

The goal of inclusive education is to create a process that enables students to learn in their own learning community (Slee, 2014) and allows students to reach their full learning potential (Booth \& Ainscow, 2011). For many, it also means feelings of belonging to your school community (Qvortrup \& Qvortrup, 2018).

Yet, there is a paucity of literature about how inclusive pedagogy should be enacted in classes (Florian \& Spratt, 2013). Many researchers have criticised inclusive education particularly concerning its practical realisation as it simplifies the complicated reality and students' heterogeneity (see, e.g. Norwich, 2013). In heterogeneous classes, teachers often confront obstacles in resources, such as time, materials, physical class spaces and personnel (Lingard \& Mills, 2007). Many teachers find it demanding to consider students' various interests and preferences for studying in groups or alone (Joseph et al., 2013). There is a danger that many students with diverse needs may be left without support, if the teachers in the mainstream classes are not able to teach diverse students (Lumby \& Coleman, 2016). For example, in Hienonens et al.'s (2018) large-scale longitudinal study, the learning outcomes in classes with students with special educational needs (SEN) and students with any additional needs, both groups performed on mean lower than the students in classes without students with SEN.

Inclusive education in mainstream classes needs teachers who are able to do flexible solutions in constructing the learning environments for all their students. According to Buyse et al. (2008), the core dynamic is indeed on teachers' professional skills and supportiveness, which positively influence the school climate, learning processes, academic outcomes and non-conflictual relationships in the classroom. Spratt and Florian (2015) see the inclusive teacher's relevant competence as the ability to support each individual in the context of 'everybody'. Tjernberg and Heimdahl Mattson (2014) argue that teachers who implement inclusive education have a positive belief in their students' abilities and that they are committed to teaching everyone. In the context of inclusive education, a teacher could be seen as an educational designer, who is able to be a reflective practitioner and to develop her/his own work guided by inclusive values (cf. Nielsen \& Andreasen, 2013).

In this chapter, we are interested in what kinds of teacher competence is needed when teaching diverse pupils in an inclusive school. According to Koster and Dengerink (2008), teacher competence includes a combination of knowledge, skills, attitudes, values and personal characteristics that allow the teacher to act professionally and effectively in particular teaching and learning situations. In this chapter, we describe our collaborative action research on teacher competence in the context of inclusive education and universal design for learning (UDL). The main goal of UDL is to make educational environments at all levels more inclusive. The values of the UDL approach indicate appreciation of the variability and diversity of learners (Rose et al., 2014). Thus, UDL can be seen as quite a comprehensive pedagogical approach of inclusive education (cf. Jimenez \& Hudson, 2019). As such, it can help 
to cover the gap between inclusive ideals and practice. Even though there has been an increasing number of studies on inclusive educational settings, research focused on the skills and knowledge of qualified inclusive teachers is still scarce (see, e.g. Florian \& Black-Hawkins, 2011). With our research, we aim to fill this gap.

The research was carried out as a case study together with two co-teachers and a first class teacher, who implemented UDL in their heterogeneous classes in Finland. In this chapter, we analyse the pedagogical activities of the adults who participated in our research. We collaborated with the teachers by acting as researchers studying their teaching, and as mentors helping the teachers to develop their pedagogy as they started trialling UDL in their teaching.

\subsection{UDL and Teacher Competence in MAP Model}

In analysing teacher competence in this study, we will utilise the theory-driven multidimensional adapted process (MAP) model of teaching developed by Finnish researchers in the project Student Selection to Teacher Education in Finland Anticipatory Work for Future (Metsäpelto et al., 2020). The MAP model is based on the research by Blömeke, Gustafsson and Shavelson (2015), and it has been developed in the context of Finnish university-based teacher education. The teacher educators and researchers from Finnish teacher education units participated in the development of the model by reviewing literature. Like Blömeke et al., they see teacher competence as a multi-dimensional continuum expanding both horizontally and vertically. The MAP model combines the teacher's dimensions of competence and the situation-specific skills that are used when applying one's pedagogical practices. Finally, the model considers teacher effectiveness on the students' level (see Fig. 10.1).

Our purpose is to identify the cognitive and the non-cognitive - that is, the affectmotivational latent - factors in teacher competence through the analysis of teachers', TA:s' and pupils' observed performance in the research classes and their perceptions of teaching and learning that took place in the classes.

In our study, the UDL approach represents the observable professional practices of the model. By analysing them, we will detect the situation-specific skills related to UDL and through these we will draw on teacher competence. The MAP model sees the pupils' experiences of learning, motivation and well-being as a sign of the teacher's effectiveness. The students' perceptions are important indicators of the effectiveness of the UDL approach implemented in the research classes.

The MAP model identifies pedagogical practices at the individual and group levels and at the organisational level as well as at the local, national and global levels (Metsäpelto et al., 2020). On the national level, Finland's compulsory education is organised quite unanimously, and the general principles governing education and education policy are planned, outlined and implemented by the Parliament, the Ministry of Education and Culture and, as part of the Parliament, the Finnish National Board of Education (Ministry of Education and Culture, n.d.-a). However, 


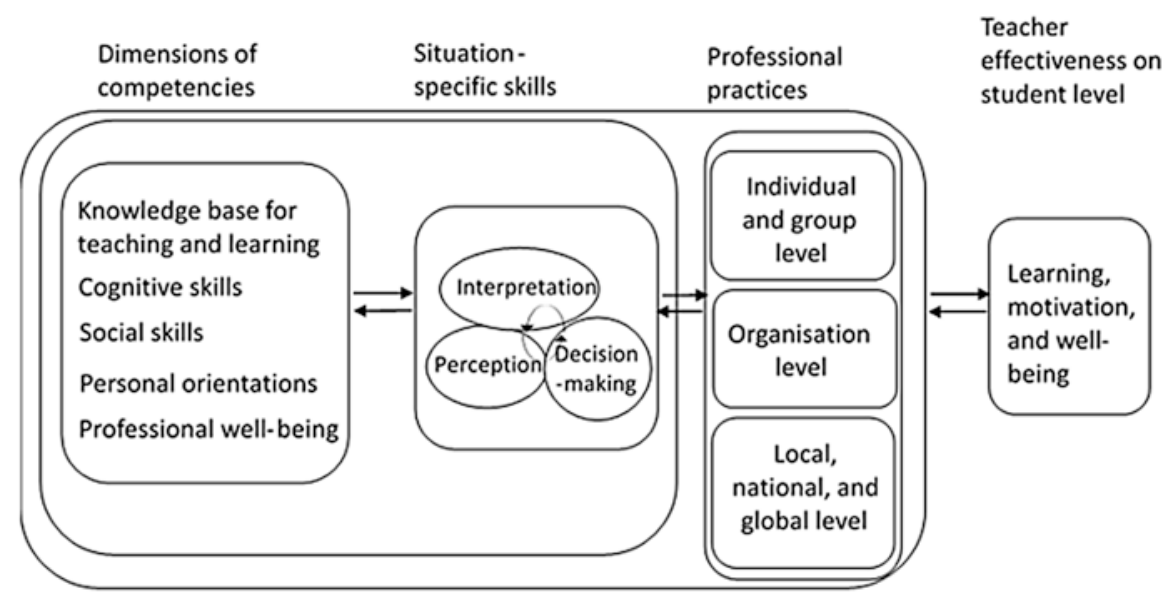

Fig. 10.1 Multidimensional adapted process (MAP) model of teaching (Metsäpelto et al., 2020)

locally, the Finnish municipalities are allowed to apply some curricular features that are considered characteristic to the specific region (Finnish National Agency of Education [FNAE], 2016).

In Finland, all people have the right to education free of charge in accordance with their abilities and special needs. Compulsory education begins the year children turn 6 and ends the year when they turn 17. All the students who have completed their compulsory education have a right to continue their studies either in general or vocational upper secondary education. The Basic Education Act (628/1998) sets the principles and norms of basic education (compulsory education). There are no national tests for students, and the nature of the evaluation of learning outcomes at schools is encouraging and supportive (Ministry of Education and Culture, n.d.-b). The compulsory education is steered by the National Core Curriculum for Basic Education, which forms the national framework for the local curricula. The local education providers are responsible for the local curriculum and also for providing early childhood education and care, pre-primary education and basic education to all who live in their municipality (see Ministry of Education and Culture, n.d.-a; Finnish National Board of Education, n.d.). The Finnish educational policies expect the teachers to organize the support for their students in collaboration with other teachers and professionals at schools. In general, it can be stated that the Finnish teachers' pedagogical position is autonomous as they have freedom to decide about many pedagogical issues and practices themselves.

Relevant to our case's pedagogical practices are the individual, group and organisational levels as well as the local level. By taking these levels into consideration, we aim to detect the teacher competence characteristic to UDL teaching. Furthermore, we will parallel UDL teaching with inclusive pedagogies in detecting the dimensions of teacher competence (cf. Jimenez \& Hudson, 2019). 


\subsection{The Collaborative Action Research Rationale}

Our research is a practice-oriented longitudinal case study (Yin, 2014), where two teachers - a class teacher and a special education teacher - teaching the same group as co-teachers, and their colleague, a class teacher with her class, implemented the UDL approach in their heterogeneous classes. The research strategy can be characterised as collaborative action research, whose ontological starting point is the people's socially constructed knowledge (Brydon-Miller et al., 2003). This action research comprises a range of data collecting methods and data, like observations, interviews, mentoring discussions and surveys.

In the orientation cycle, during the academic year 2017-2018, the researchers collected research data about the pupils and the co-teachers in the research class. The co-teachers' pedagogical practices were observed and identified in theoretical frames. Then, during the autumn semester of 2018, the co-teachers were trained to understand the principles of UDL. During January and February of 2019, the teachers developed and trialled UDL periods in their classroom. The researchers collected data from the pilots and had mentoring discussions with the researchers. The final outcome from the first cycle was to sketch the next action research cycle based on the analysis of the UDL trials.

In the second cycle, the co-teachers applied UDL as thematic periods with their pupils. In order to get more feedback from their teaching with UDL, the co-teachers and researchers decided to invite a class of first-graders and their teacher to join the UDL teaching periods in the autumn term of 2019. The second action research cycle generated the actual data for the final conceptualisation of teacher competence needed while implementing UDL in teaching.

The third cycle took place in the spring term of 2020, when the researchers distanced themselves from the actual field of teaching and started to analyse the data in the theoretical frames (Yin, 2014) of teacher competence. The analysis of the teachers' development and implementation of UDL in the research classes was carried out utilising the MAP model. These conceptualisations are introduced at the end of each subsection of an UDL principle.

The research took place in the North of Finland which is a sparsely populated area. The demographic structure of the region sets challenges for schools. The support services, for example, the central hospital, is situated in the nearest town, over $100 \mathrm{~km}$ away. Consequently, the teachers and the local authorities need to be innovative and collaborate in order to organise the support for the students as effectively as possible. In addition, the school is situated in the Sámi region, in Finnish Lapland, where the only indigenous people in Finland live. This means that teaching needs to be culturally sensitive and encourage all children to respect their own and other students' roots. The research classes were heterogeneous in that they have pupils with diverse needs, including pupils with special educational needs. The action research started in autumn 2017 in one class of first-graders (7-year-olds). In the class, there were two teachers starting their collaboration, a class teacher and a special education teacher, who taught as co-teachers. In Finnish schools, there are 
teaching assistants (TA:s) who support teachers' work as the teachers act as pedagogical leaders in their classes. The TA:s may support the whole class or they may be appointed as personal assistants for certain students with SEN. In the research class, there were two TA:s for the whole group, and two TA:s as personal assistants for certain pupils.

In Finnish comprehensive school, there is a three-tiered support system for learning which gives flexible conditions for organising the educational support for students in mainstream settings. The tier of special needs is the third and strongest form of support for learning in Finnish compulsory education, requiring a formal administrative decision and an expert's report after being processed in a multi-professional student welfare group and parents (FNAE, 2016). The second tier of support, which is referred to as intensified support, is meant for pupils who have mild difficulties in their studies or who are at risk of marginalising. The decision on this tier needs to be agreed in a multi-professional student welfare group together with parents (FNAE, 2016). The general support is meant for all pupils (FNAE, 2016).

During academic year 2017-2018, there were 17 pupils, of which 8 had a decision of special needs support (SEN) and an individual education plan (IEP). Four of the pupils with SEN were in extended compulsory education, of which one pupil's IEP was arranged by activity areas. One pupil of the class was in the tier of intensified support. There were nine pupils in the class on the tier of general support. During the research years, some changes occurred while some support decisions moved up or down the support tiers and some pupils moved away or new ones entered the class. On the second grade, there were 18 pupils and on the third grade, there were 20 pupils in the class.

During the second cycle of action research, for the actual UDL periods in autumn 2019 , the co-teachers invited a partner class. The purpose was to obtain more feedback and disseminate the knowledge on UDL. In the partner class, there were 20 first-graders, one class teacher and one TA. One of the pupils was in the tier of intensified support and two were non-Finnish-speaking pupils. So altogether, for the UDL periods in autumn 2019, there were three teachers, three TA:s for the whole group, two personal TA:s and 40 pupils.

The research agreement was made with the municipal school government, the school principal and the teachers. The researchers and the teachers carefully informed the TA:s, pupils and their parents of what was going on in their classes. The TA:s, the parents and pupils were given an informed consent, which included relevant information about the research goals and the ways of publication as well as the possibility to withdraw from the research whenever they wanted (Cohen et al., 2011). In the research results, pupils were given pseudonym names and the adults were called by their position as co-teachers, first class teacher and TA:s. 


\subsection{The Finnish Case - UDL Principles in Terms of Teacher Competence}

Although the UDL framework is, overall, an entity, we will introduce our results by viewing each UDL principle one at a time. First, we will explore the teachers' pedagogical practices and their development during the teaching processes. Through the exploration, we will detect the situation-specific skills needed in the chosen pedagogical practices. In addition, we will analyse the pupils' perceptions of their own learning before and after the UDL lessons, and investigate the changes that appeared in the pupils' learning experiences and motivation. Finally, we will interpret the connection with the teacher skills found in our research and the expected teacher competence according the MAP model, reflecting on them in accordance with previous research. The procedure of our research is illustrated in Fig. 10.2.

In the following subsections, the teachers' development and skills are described according to the first and second cycles of our action research. The third cycle of our action research becomes visible at the end of each subsection, when we conceptualise the connection with the skills and the expected teacher competence according the MAP model.

\section{The Co-teachers Create a Safe and Motivating Learning Environment}

We will start our examination by scrutinising the co-teachers' pedagogical practices that are linked to the UDL principle called the multiple means of engagement. This principle deals with the 'why of learning', in other words, it describes the means to enhance students' motivation towards and engagement in their studies.

The autumn semester in 2017 was well under way when we visited the coteachers' research class for the first time. The first-graders were not very far in their

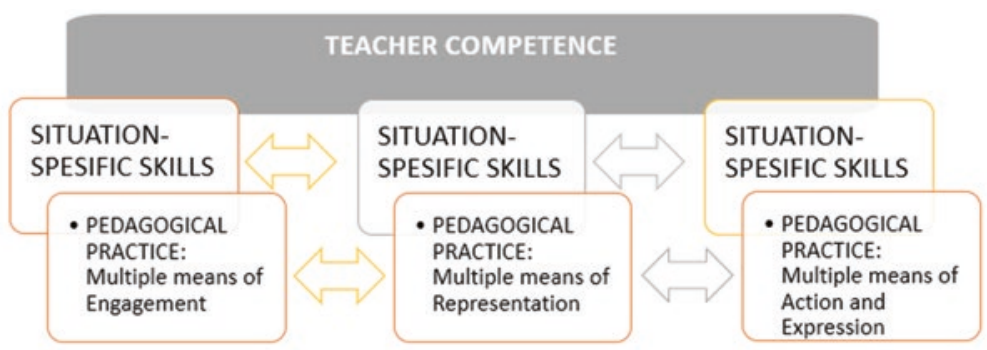

Teacher effectiveness on the student level: Learning, motivation and well-being

Fig. 10.2 Research procedure in the frames of the MAP model of teacher competence 
academic studies; they had only learnt a couple of letters and numbers so far. What caught our attention, however, was the tranquillity in the pupils, co-teachers and TA:s' actions. Various work methods were used during the lessons, but the pupils always seemed to know what to do. At times, they consulted one another about an assignment or discussed it with the teacher or teaching assistant, but the atmosphere in the class remained peaceful and comfortable. The co-teachers told us that the main goal of the autumn semester was to teach the pupils how to study and work together (Observation and mentoring discussion, 12 Oct 2017).

In the spring 2017, after having permission from the school's administration for the joint class of special needs children and children on the tier of general support, the co-teachers had started planning their work. From the very beginning, the coteachers invested in engaging the parents in their work. As early as the second school day evening, they invited the parents and carers to a parents' meeting and explained the principles behind their teaching. Their goal was to teach diverse children to study together according to their own potential and to bring up the pupils as tolerant persons. The co-teachers stressed the importance of appreciating the parents' opinions and knowledge. During parents' meetings, they asked the parents to generate ideas for trips and asked them about various volunteer tasks. They also invited parents to visit the class and asked that the visitor describe his/her own work, such as reindeer herding, which is an important livelihood in the region.

Some of the fathers [during the parents' meeting] were like: 'Wow!' The parents asked: 'When will this happiness end?' (Co-teachers in mentoring discussion, 12 Oct 2017)

For example, when we had an excursion to the woods, one of the fathers, a reindeer herder, came to talk about the eight seasons in which the reindeer herding affairs are set. (Co-teachers in mentoring discussion, 22 Nov 2018)

The co-teachers took basic guidelines from the seven cross-curricular skills mentioned in the Finnish core curriculum (FNAE, 2016), especially the skill referred to as thinking and learning to learn. The aim there is that pupils learn to observe and search, evaluate, modify, produce and share information and ideas as well as reflect on themselves as learners and interact with their environment (FNAE, 2016).

The point is there are the cross-curricular skills and inside them the single school subjects. For example, the meaning of pupils' meta-cognitive skills, how they are expected to learn how to assess their learning. After all, that is the most important thing, to learn to see yourself as a learner, to see your own strengths. (Co-teachers in mentoring discussion, 12 Oct 2017)

At the beginning of the first semester, the co-teachers noticed that many of their pupils, especially those with difficulties in learning or concentration, had a low selfesteem. This notion led them to apply positive pedagogies in which the co-teachers focused on pupils' strengths, supported them in growing persistence and giving them experiences of success.

We have tried to apply a positive [pedagogy]. It means that we constantly work to support these children. Their self-esteem is extremely weak. They almost every time say that 'I' $m$ bad', I can't', 'I'm good for nothing'. (Co-teachers in mentoring discussion, 12 Oct 2017) 
All the adults in the research class had a child-centred and positive way of thinking. They believed in the pupils and their opportunities to learn despite learning and other difficulties. Actually, they rather saw difficulties in the teaching than in the learning. That is why they continuously monitored their pupils' learning processes. They also tried to give positive feedback as much as possible.

Co-teacher: Perhaps the most important thing, I think, is what we have decided: that we believe that a child will learn. (Co-teachers in mentoring discussion, 8 Nov 2019)

'The pupils with SEN couldn't start working on their own. [...] Two lessons were too short a time for SEN pupils. The special needs teacher and the teaching assistant noticed these challenges and set out to think about the learning package more next time from the perspective of SEN pupils. (Co-teacher's notes, 17 Jan 2019)

The co-teachers introduced the pupils to the story of Winnie the Pooh and used the characters of the story when the pupils learned self-assessment (see Picture 10.1). The aim was to systematically develop the pupils' metacognitive skills in a way that corresponded to the pupil's cognitive level. The children could relate to the various characters according their feeling after having accomplished their learning task. Furthermore, the identification of the learning process was enhanced when the pupils were able to hear each other's evaluations.

The pupils sit in the circle. On the table, each soft toy represents a character from the Winnie the Pooh stories. Each toy also has an emoji that matches the toy's character. Self-evaluation begins: the pupils pin their own wooden clothes peg with their name on it to a toy figure that corresponds to their sensations of doing in the previous school task. Then each pupil presents reasons for their solutions. For example, Anna is frustrated because during the [previous] exercise, she twice accidently picked up the same word for the worksheet. Her assessment is analysed appropriately as a whole. (Observation, 15 Jan 2018)

The co-teachers taught their pupils' social skills and paid attention to the positive internal social relationships in the group. They took advantage of pupils' real decision-making situations and had profound discussions with their pupils. Overall,

Picture 10.1 The toy characters facilitating the pupils' self-assessment

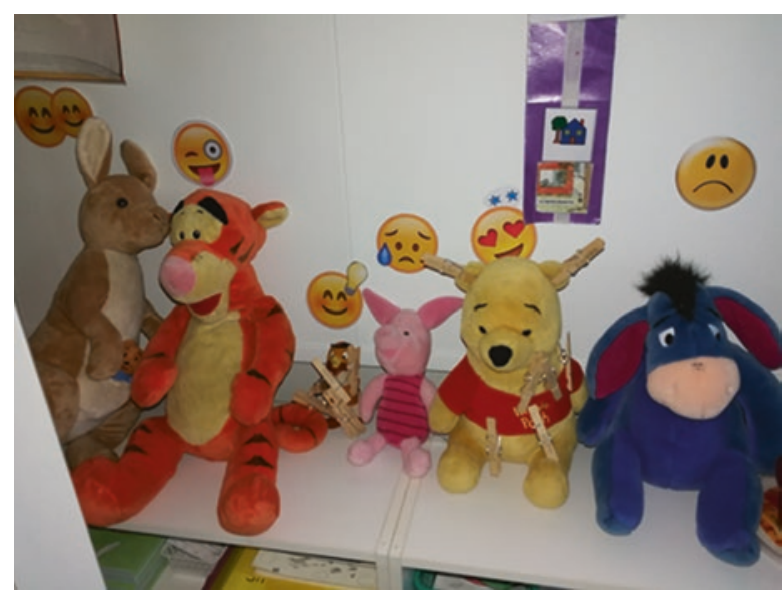


the co-teachers had made a conscious decision that their first priority was to proceed peacefully and, above all, teach their pupils how to study.

During the break, the pupils pretended to be a reindeer herd. They had a problem of who got to be the lead reindeer. If there are many of them, the herd will fall apart, the children said. The co-teacher asked what kinds of suggestions the pupils have for solving the problem. They discussed different options. Eventually they decided they all can be the lead reindeer on their own turn. (Observation, 22 Nov 2018)

Two examples of the girl who came to the class the second year, show that the pupils' internal relationships were strong and that the co-teachers had managed to teach the pupils social skills and a sense of togetherness.

At the beginning, Nina had difficulties and challenges. She could have tantrum, lie on the floor and kick. But the other pupils did not become disturbed at all. One time I was at the front teaching. The pupils were sitting in a row on the benches. Nina was yelling very loudly at the back of the classroom. No one turned their heads, they just concentrated on my teaching. (Co-teachers in mentoring discussion, 22 Nov 2018)

In the previous situation, the pupils knew that the special needs assistant would handle Nina's tantrum. They were discreet and pretended to notice nothing. Another example shows that the pupils felt empathy for the new girl and wanted her to feel comfortable in the class:

It was like a diamond moment when Nina went to strike and did not want to take a nap [Nina had to rest during the school day during the first months at school]. The teacher and the personal assistant could not make her agree to go to sleep. Then a boy with many difficulties in behaviour himself stood up, went to take Nina by the hand and said: 'Come now Nina, now you will have a nap'. And the girl followed him nicely to the rest room. (Co-teachers in mentoring discussion, 22 Nov 2018)

We will now look at the teacher's effectiveness on the student level. According to MAP model, it can be demonstrated through the students' learning, motivation and well-being (Metsäpelto et al., 2020). We used a research-based Finnish survey, called 'I as a schoolchild' (Aro et al., 2014). We carried out the survey at the beginning of the first grade's spring semester (15 Jan 2018) and at the end of the second year's spring semester in 2019 (7 May 2019). We interviewed the children individually because not all of them could read at that point. The pupils answered the propositions by assessing them via a Likert scale. We used emojis ranging from a smiley face (I agree) to a sad face (disagree) to support the verbal instructions. For the assessment of the pupils' engagement in school, we selected three items from the survey. The pupils' experiences were already quite positive during the first grade, but at the end of the second grade, they were even more positive. However, in 2018 there were two pupils with SEN whose feelings were quite negative. Their answers showed that they did not enjoy going to school, their class or the school as a whole. The answers concerning the pupils' enjoyment of school are illustrated in Table 10.1.

During the pupils' second school year, in spring semester of 2019, we mapped the internal peer relationships in the class. The sociograms with the question asked are demonstrated in Figs. 10.3 and 10.4. The sociograms are divided into zones which describe how many mentions each pupil got. The pupils with SEN, intensified 
Table 10.1 Co-teachers' pupils' answers on how they enjoy going to school

\begin{tabular}{l|l|l|l|l|l}
\hline Item & Year & Agree & Sometimes agree & Disagree & $\sum$ \\
\hline I like going to school & 2018 & $81.3 \%(13)$ & $12.5 \%(12)$ & $6.3(1)$ & $100.0 \%(16)$ \\
\cline { 2 - 6 } & 2019 & $85.7 \%(12)$ & $14.3 \%(2)$ & - & $100.0 \%(14)$ \\
\hline I enjoy my class & 2018 & $87.5 \%(14)$ & - & $12.5 \%(2)$ & $100.0 \%(16)$ \\
\cline { 2 - 6 } & 2019 & $100.0 \%(14)$ & - & - & $100.0 \%(14)$ \\
\hline \multirow{2}{*}{ We have a nice school } & 2018 & $81.3 \%(13)$ & $5.3 \%(1)$ & $10.5 \%(2)$ & $100.0 \%(16)$ \\
\cline { 2 - 6 } & 2019 & $92.9 \%(13)$ & $7.1 \%(1)$ & - & $100.0 \%(14)$ \\
\hline
\end{tabular}

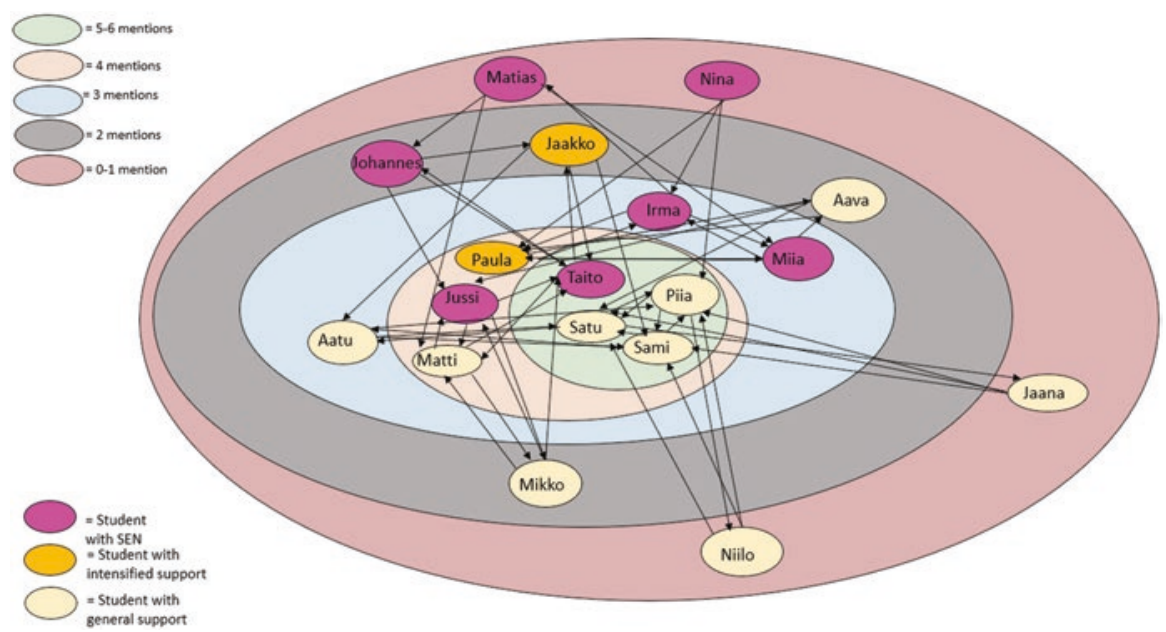

Fig. 10.3 Co-teachers' class, sociogram answering the question: In our class we study by doing group work. Which three classmates will you choose for your group?

and general support are coloured different colour. At first, the pupils were instructed to imagine they were studying by doing teamwork, and they were asked to name three classmates with whom they would prefer to study. All the pupils, except Nina, was named at least once (Fig. 10.3). However, the result of the sociograms can be regarded as good because there are mentions between pupils with different tiers of support, and most every pupil received mentions. The reason why Nina did not get any mentions was probably due to her severe learning difficulties. Her most important goals at school were learning to follow the teachers' instructions, such as to sit in one place for a few minutes, to listen to a story or to take care of her needs in going to the toilet. She was also learning to express herself through some short words.

The second question addressed to the pupils was 'With whom would you not like to play during the break?' (Fig. 10.4). The results show that Johannes (eight mentions), a boy with ADHD, was the least-wanted playmate. This result can be explained by his behavioural symptoms that may cause conflicts while playing. The second least-wanted play mate was Irma (three mentions), who was a pupil with 


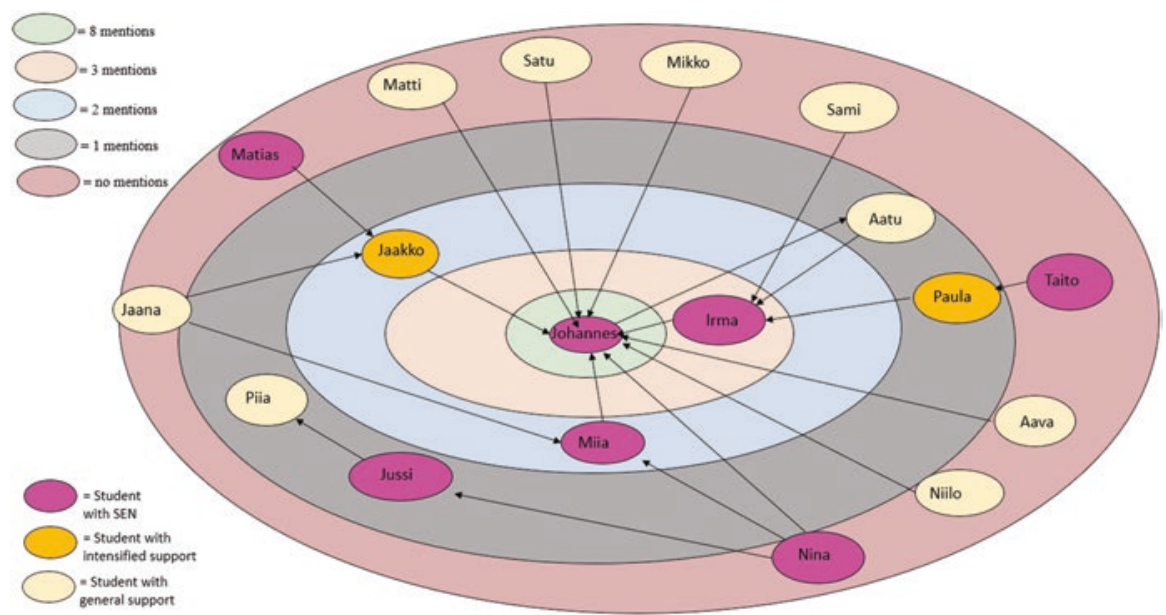

Fig. 10.4 Co-teachers' class, sociogram answering the question: With whom would you not like to play during the break?

SEN, too. Otherwise there were only one or two mentions for certain pupils, and they were pupils with all three tiers of support.

The difference between the two sociograms shows that at school there are various social arenas in which pupils are included at diverse levels (cf. Qvortrup \& Qvortrup, 2018). In the light of the survey and sociograms, the atmosphere in the class appeared generally good but still with some problems.

In the following section, we will conceptualise the co-teachers' pedagogical practices in light of the previous literature to see what kind of teacher competence is needed while building the class community and engaging the pupils in their studies.

Teacher Competence and Multiple Means of Engagement In summary, the analysis of the co-teachers' pedagogical practices shows that even before the introduction of the UDL approach, the co-teachers used the same kinds of pedagogical solutions as used in the UDL approach in regard to its principle of multiple means of engagement. The pedagogies resonate with previous research on inclusive education, too.

In the MAP model, the competence needed here is placed in the dimension of non-cognitive competence, especially a teacher's social and communication skills and personal orientations (Metsäpelto et al., 2020). They contain five sub-categories of relational skills, emotional competence, diversity competence, intercultural competence and interaction. They all fit in the pedagogical profile of the co-teachers in our study. To begin with, the co-teachers were very sensitive to the pupils' needs and engaged in supporting their pupils (see e.g. Tjernberg \& Mattson, 2014). The coteachers listened to their pupils and strengthened their sense of belonging which is considered an essential feature in inclusive education (Qvortrup \& Qvortrup, 2018) and an element that contributes to students' well-being and learning (Burke \& Claughton, 2019). As skills, these pedagogical actions can be interpreted as teacher 
commitment and sense of responsibility to their students (see e.g. Shani \& Hebel, 2016). In turn, the competencies that underlie these skills are the teacher's personal values, attitudes, beliefs and experiences (e.g. Levin \& He, 2008).

From the MAP model's personal orientations, we include here the teachers' personal dispositions, such as general patterns of adaptation, as well as self-conceptions constructed by one's beliefs, values, ethics and teacher's motivational orientation. These aspects initiated the teachers to give emotional support for their students (Lakkala et al., 2020) - instead of being distant and information oriented, seeing him-/herself as a transmitter of academic knowledge (cf. Hargreaves, 2000). According to inspections reported in the literature, a teacher's emotional support predicts a broad range of social and task-oriented competencies of students (Hamre \& Pianta, 2005).

In the MAP model, the teachers' cognitive thinking skills resonate with the pedagogical actions promoting students' metacognitive skills. They tell about the coteachers' abilities to reflect on their teaching and adjust it according to their pupils' needs (Lingard \& Mills, 2007). This dimension consists of five sub-dimensions of teachers' ability for information processing, critical thinking and problem-solving, creativity, communication, argumentation and reasoning and metacognition. The co-teachers followed the UDL principle of multiple means of engagement when they taught their pupils self-assessment in ways that matched their cognitive development to enhance their self-understanding and metacognitive skills (Elder, 2010). By teaching their students abilities to progress in their studies, the teachers also prevented social inequality (cf. Lingard \& Mills, 2007). When doing so, they accentuated their pupils' transformation as learners, a feature linked to inclusive pedagogies as well (Florian \& Spratt, 2013). Furthermore, by applying informational and encouraging feedback (Ryan \& Deci, 2016), they enabled the interaction between the curriculum and the learner (Rose, 2014), which is one of the essential ideas of the UDL approach.

One aspect in the co-teachers' pedagogy, which is not clearly explicated in the UDL approach, was collaboration with parents and carers. In contrast, this aspect is well illustrated in inclusive pedagogy. For example, in a well-known international project called Teacher Education for Inclusion, the ability to collaborate was identified as a crucial inclusive teacher's skill (Watkins \& Donnelly, 2012). In our case, the co-teachers invested in good relationships with the parents and carers as well as reciprocal co-operation.

As a conclusion, from the developmental point of view, the co-teachers were already competent to implement the first UDL principle. The only developmental aspect that could be detected was that through our mentoring discussions, the essential features of this UDL principle and its connections to other conceptual frameworks became clearer to both the co-teachers and researchers. Next, we will continue our analysis with the second UDL principle - multiple means of representation and examine the teachers' pedagogical actions related to this UDL principle. 


\section{The Teachers' Develop Their Pedagogical Practices}

The UDL principle called multiple means of representation in our research deals with the 'what of learning', describing the means to reduce students' learning barriers to perceive information (Rose et al., 2014). It is the teachers' responsibility to find the most appropriate ways to access the contents of learning.

In part, the next results describe the co-teachers' pedagogical actions in their own class when they were studying the UDL approach and trialling it with their pupils (spring term 2019). Partly, the data excerpts date from the period when the coteachers invited a class of first-graders, their teacher and one teaching assistant to join their UDL teaching (in November 2019).

Sometimes the co-teachers used embedded instruction, which means they utilised natural opportunities during the school day to teach a skill or to enhance a pupil's self-efficacy, social skills and tolerance (see e.g. Kurth \& Gross, 2015). For example, during the story telling sessions, when the pupils rehearsed oral comprehension, the teachers assured that everyone got experiences of success by planning in advance what questions were addressed to the two pupils who had severe learning difficulties or used a communicator in their communication (Observation, $15 \mathrm{Jan}$ 2018). Another example describes the ways that the co-teachers enabled a pupil with attention deficit to access the information taught.

The children sit on a row of benches, and the teacher begins to read a story. Everyone listens, except that Johannes moves about in his seat. Johannes whispers something to the teaching assistant. The assistant nods, and Johannes goes and fetches a colouring picture and pencils. He returns to his seat, listens to the story and draws while listening. (Observation, 15 Jan 2018)

Mostly in the co-teachers' class, especially during reading or math lessons, the pupils worked in groups, named after colours, in order to get timely and targeted support for their learning needs. Many times, the teachers divided the pupils into three groups with various exercises (see Picture 10.2). These tasks were variations on the same theme. The tasks were tailored according to the pupils' learning profiles.

The co-teachers also used other kinds of groupings, such as station working, where the children either played a game or did math exercises or functional tasks. The co-teachers' goal was to strengthen their pupils' self-efficacy by providing them tasks in which they could succeed. As one of the co-teachers said:

Scale, fit, differentiate. Everything you do, make it the size of the child, so that he/she can experience success. And if she/he fails in the task, the pupil should feel that 'Hey, we got over this problem together!' (Co-teachers in mentoring discussion, 22 Nov 2018)

The co-teachers started trialling UDL in their class in spring term 2019. Their theme was the human body and its functions. They used the flexible groupings for targeted support (blue, green and red groups). The first trial showed that the green group of pupils with SEN had trouble understanding the instructions and learning tasks. For the next UDL trials, the co-teachers developed the learning tasks to be more accessible to the whole group. The pupils had mutual starting and ending 
Picture 10.2 Instruction for flexible grouping during math and reading lessons for the blue, green and red groups, co-teachers' class

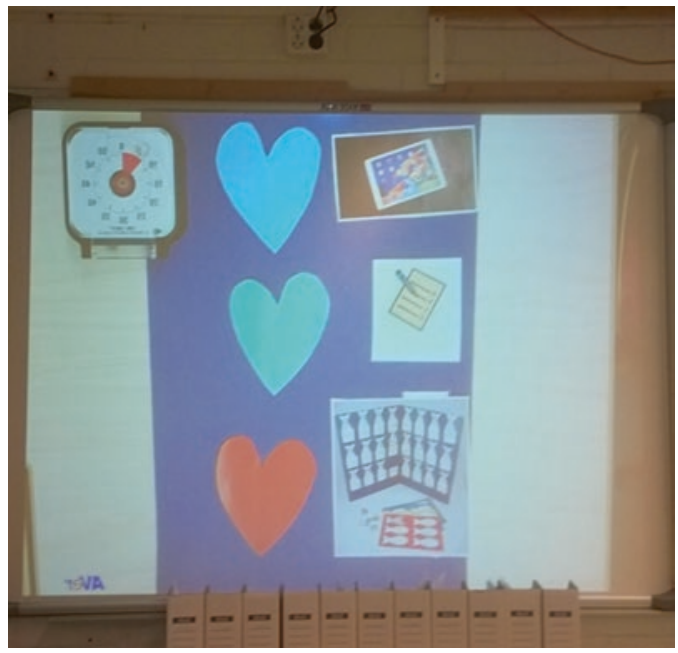

points for the lessons, for example, the pupils watched parts of the series 'Once upon a time... the life' animation film (Co-teacher's notes, 31 Jan 2019). They planned more concrete learning material for all. Still, they continued to prepare tailored material, too, because of the severe learning difficulties of the pupils with SEN. In addition, during the lessons, the co-teachers and the TA:s guided the groups carefully. They also gave more time for the pupils' learning.

We had a mutual start where we looked at the pupils' baby photos [that they had brought from home]. Lovely moment! We discussed a lot. Then we had the working session in small groups. All the groups had tailored exercises about the same topic. The green group [pupils with SEN] started following the pattern well proven by using the easy-to-read text tailored for them. The other two groups studied the topic autonomously from the books. After the various exercises, we watched an animation film about human functions. (Co-teacher's notes, 31 Jan 2019)

The co-teachers continued further developing the UDL trials. They started giving the pupils options for the learning tasks while the topic was the same. The options enabled their pupils to choose the way to study in which they learned best. The instructions were given both verbally and pictorially (see Picture 10.3).

After the UDL trials in their own class, the co-teachers carried out two actual UDL periods. They invited a class of first-graders, their teacher and their teaching assistant to join the periods. In November 2019, they started with the topic of Lappish animals. At the beginning of the UDL session, the pupils were given instructions through verbal and visual explanations, and they were divided to small heterogeneous groups. Each small group had at least one pupil following the tier of general support, a third-grader, one pupil following the tier of intensified support or a pupil with SEN (a third-grader), and one first-grader. Because there were pupils of various abilities and ages, they could choose different ways of producing the knowledge/outcome about the mutual topic. 


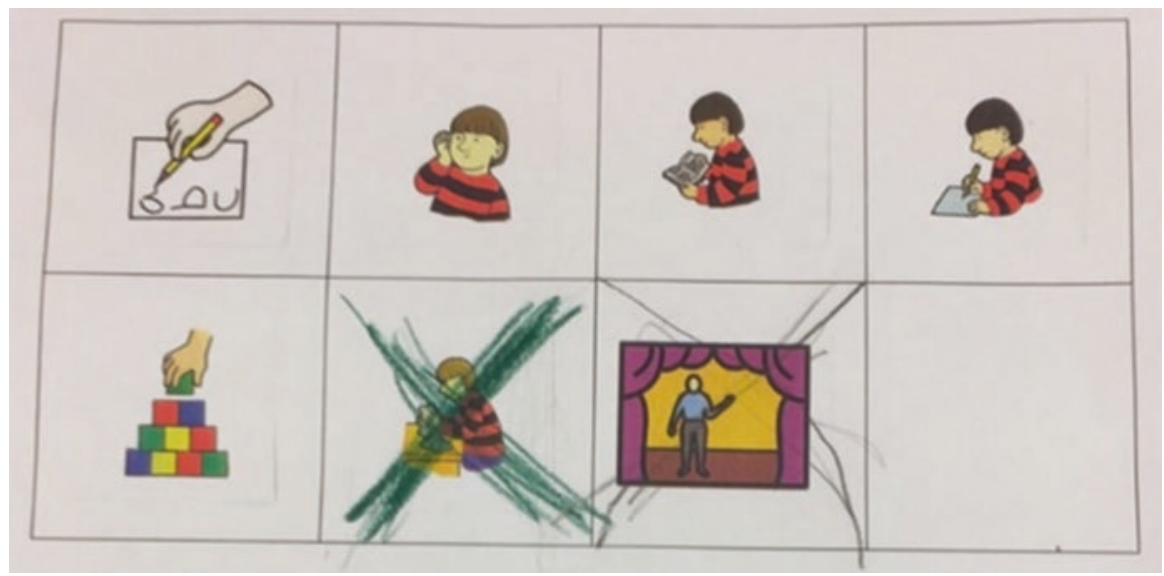

Picture 10.3 The options for the learning tasks for the lesson, pictorial instruction and coteachers' class

The pupils are divided into heterogeneous small groups (first- and third-graders). One of the teachers explains and shows how to work with the day's topic. The pupils can search information on an iPad (animal document films) or in a book. The younger ones or the children who cannot read can listen when the pupils who are literate read aloud. They can make notes, sculpt playdough or draw (the Lappish animal they are studying). (Observation, co-teachers' class and first graders, 8 Nov 2019)

During the second UDL period, the teachers continued to reflect on their teaching and the pupils' learning. In spite of some groups needing strong guidance, the adults tried to give space for their pupils' autonomous choices. The pupils were creating animal tales in the same kind of mixed-aged small groups as before.

The small group of Miia, Jussi, Irma and Matias needed much guidance on how to study together. Even coming up with the mutual topic for today's task (the task was to come up with a mutual tale) was difficult. Strong guidance by an adult was needed. Some of the children will need lots of guidance for learning to collaborate. - As in teacher's role, I felt it challenging not to guide the children much in direction of my vision but tried to let the children's views show. (Co-teacher's and first grade teacher's notes, 22 Nov 2019)

After the pupils had invented a topic for the tale, they were introduced to the concept of the mind map. With the help of the mind map, they created the plot of the tale (see Fig. 10.5).

Figure 10.5 shows that the teachers highlighted patterns and critical features when the pupils were composing the tales. The mind map helped them to learn the anchor concepts and basic structure of a tale. The pupils of the group could participate in the story telling from their own starting points, some verbally, some by drawing and some by writing (Co-teacher's and first grade teacher's notes, 22 Nov 2019).

We examined the pupils' experiences of the representation of learning contents in the co-teachers' class through the 'I as a schoolchild' survey (Aro et al., 2014) twice. The pupils were asked if there are enjoyable tasks at school; whether they do the difficult tasks, too and whether they finish the tasks. The pupils (year $2018-$ $N=15$, year $2019-N=14$ ) answered the statements by assessing them on a Likert scale. The results are shown in Fig. 10.6. 


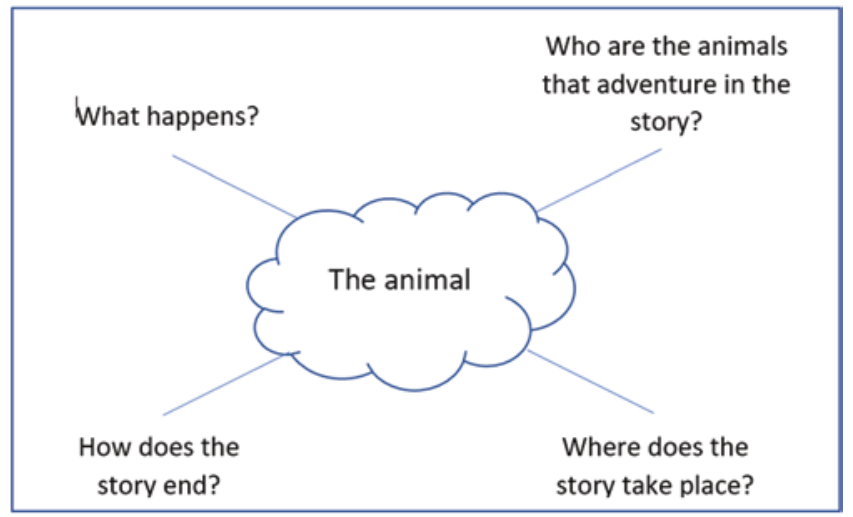

Fig. 10.5 The mind map of the tale presented for the co-teacher's and first grade teacher's pupils

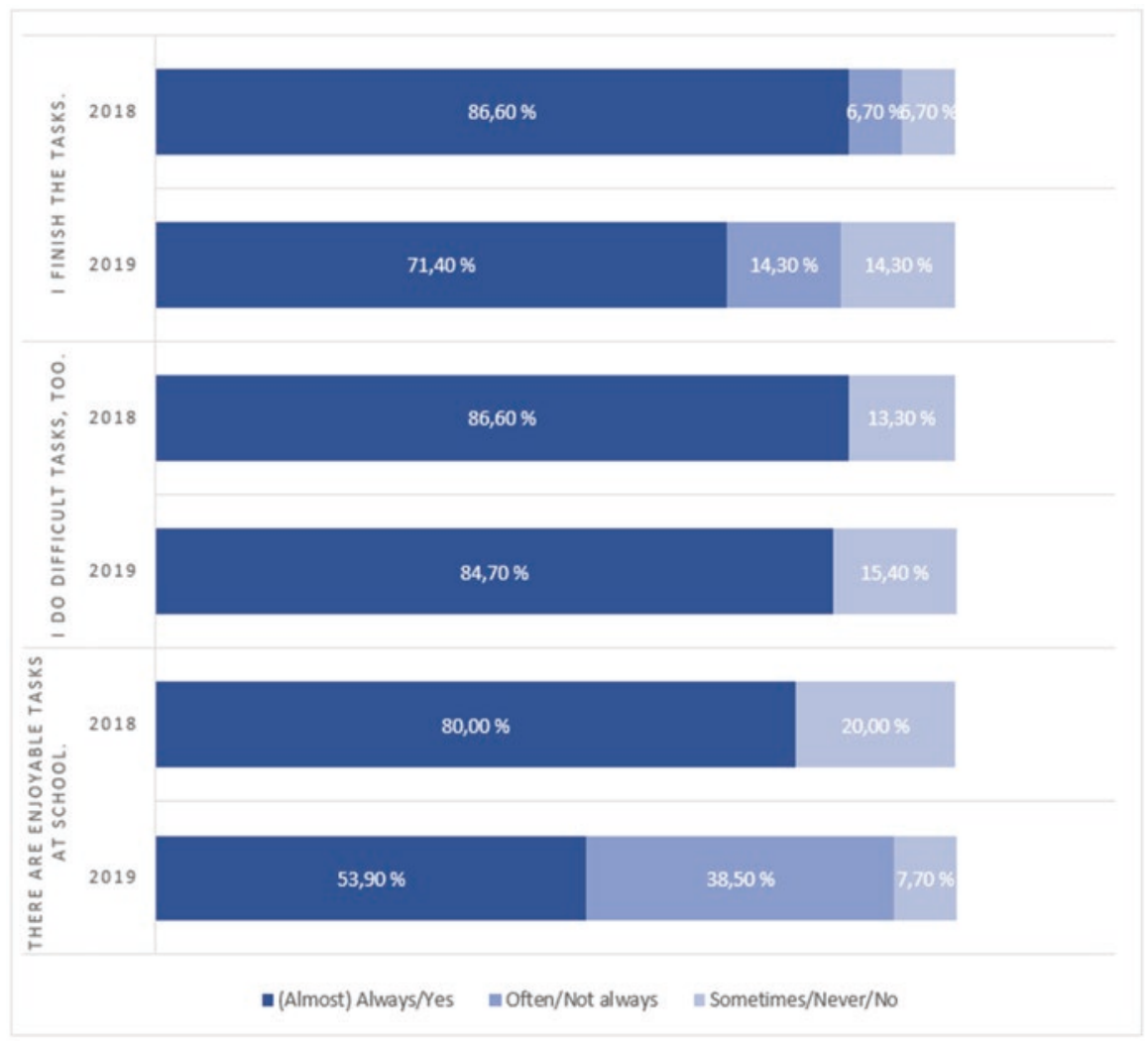

Fig. 10.6 Co-teachers' pupils' answers on how they feel about the school tasks 
In both years, over half of the pupils answered all the statements in a very positive way. However, the number of pupils with a very positive attitude towards the enjoyable tasks at school reduced during the second grade. When asking if the pupils finish the tasks, the number of strongly negative answers increased slightly in the second grade. For the question on whether the pupil also does difficult tasks, two pupils answered that they do them only sometimes or never, in both year's surveys. Both were pupils with SEN. Otherwise, all the most negative answers on all three questions were given by the same SEN pupils in both years. According to the coteachers, these pupils did not have high esteem in regard to schooling. However, we may anticipate that their self-esteem is low partly because of inappropriate tasks.

After the UDL lessons, the pupils from grades 1 and $3(N=37)$ answered a survey through which they assessed their own working during the UDL lessons. For assessment, we constructed a questionnaire called 'This is what I am as a learner' based on the UDL principles (Appendix 10.1). Three of the items were interlinked to the multiple means of representation, and their results are illustrated in Fig. 10.7. When analysing, we combined the original five categories into three categories of answers of 1 - agree or almost agree, 2 - I don't know and 3 - fairly disagree or disagree.

In Fig. 10.7, we can see that pupils' experiences with the UDL lessons were mainly very positive. However, there were also pupils whose experiences of the UDL lessons were not so positive. There were three to five pupils who answered that they had not learned, had not understood the things to be learned or had experienced the lessons as boring. We analysed the connection between the different pupils' answers with the Pearson's correlation test (Rodgers \& Nicewander, 1988). We found no statistically significant differences between the answers and the pupils' support levels: there were pupils studying in every level of the three-tiered support (general, intensified and special support) who answered both positively and

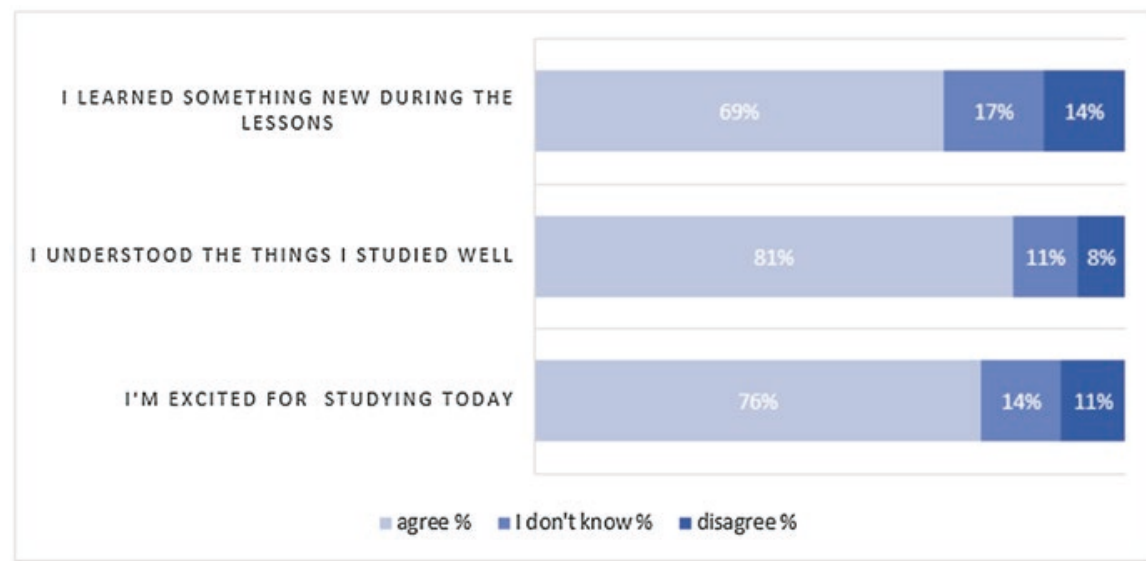

Fig. 10.7 Co-teachers' and first grade pupils' self-assessment of their learning after the UDL lessons 
negatively (see Table 10.2 in Appendix 10.2). Furthermore, there were no statistically significant differences as to whether a pupil was a first- or third-grader. Instead, we found a slight positive correlation between how excited a pupil was and how well she/he understood the things to be learned $\left(r=0.356^{*}, p=0.033\right)$. We assume that the positive correlation indicates the relevance of motivation.

Teacher Competence and Multiple Means of Representation In the MAP model, the implementation of the multiple ways of representation corresponds with the teacher competence called knowledge base for teaching and learning. The crucial sub-dimensions of this teacher competence are especially content knowledge, pedagogical knowledge and pedagogical content knowledge. This knowledge combines teachers' formal and experiential knowledge, built on their previous experiences and actions in classrooms, and on their reflections on those experiences (van Driel et al., 2001).

According to our findings, the teachers created a learning environment and atmosphere that encouraged the pupils and supported their learning. They did not use any study books; rather, their teaching was based on the curriculum, which they carefully amended and implemented (see also Lakkala \& Määttä, 2011). The teachers used self-made authentic tasks in a meaningful context. They reflected on the teaching both individually and collectively, and through that they succeeded in assessing their own actions as a teacher and in developing pupils' learning processes. They considered the pupils' previous knowledge about the subject to be learned, and they used various materials, tasks and contents depending on pupils' needs and readiness. During the UDL trials, the co-teachers realised that instead of tailoring all the learning tasks, the pupils learn to utilise their learning capacity if they are also given optional ways for learning. This, in turn, promotes the development of the pupils' thinking and learning to learn.

Furthermore, the UDL principle of multiple ways of representation is interlinked with the teacher competence called cognitive thinking skills of the MAP model. When changing their teaching strategy, the teachers showed abilities to critically analyse, evaluate, reorganise, create and expand knowledge and to find new ways to solve problems to achieve a goal (see also Krathwohl, 2002). In the MAP model, this competence contains five sub-dimensions, which are information processing, critical thinking and problem-solving, creativity, communication including argumentation and reasoning, and metacognition. The teachers were very precise with their verbalisation in order to make the learning contents accessible for their pupils. They used open-ended questions, repetitions and rich language in learning situations. Also, Pianta et al. (2008) recognise the significance of instructional support on the learning process.

As a developmental consequence, teachers managed to change their teaching methods from tailored tasks to new ways of teaching. Using UDL in the research classes encouraged pupils to have confidence in themselves and their views. When instructing the pupils in small groups, the teachers gave space to pupils' questions and inspired them to search for answers, listen to others' views and also reflect on their previous knowledge. The teachers gave plenty of feedback, challenging the 
pupils to think and ponder as well as encouraging peer feedback (cf. Hamre et al., 2013). In Pakarinen et al.'s (2010) research, they proved that high-quality instructional support increased students' task-oriented learning in the classroom. The teachers' skills of communication and argumentation resonate with higher-order thinking skills, and they are considered critical for teachers' work (Metsäpelto et al., 2020).

To summarise, we noticed differences between co-teachers' practices and the guidelines of UDL. In the UDL guidelines, mixed-ability groups are emphasised when talking about learner variability (see e.g. Ralabate, 2016). Also, in inclusive teaching methods, student grouping may be used with mixed-ability groups (Kurth $\&$ Gross, 2015). In our research, in spite of implementing UDL in mixed groups, the co-teachers also continued to use tailored tasks, and therefore the pupils with different abilities sometimes worked in their own small groups. Then the co-teachers used scaffolding, which enabled the pupils to work in their own proximal zone of learning (Vygotsky, 1978). Flexible grouping was defined by the co-teachers as grouping that is not static (cf. Radencich \& McKay, 1995). By grouping and using different teaching techniques, tasks and support with different groups, the co-teachers strived to create an optimal learning environment for the heterogeneous group (Ford, 2005).

Although tailored tasks for targeted pupils are viewed positively in many studies, there is a chance that pupils may feel stigmatised when they are placed to certain groups and when they themselves realise the reason (e.g. developmental, emotional or behavioural problems). Alternatively, the stigma associated with identification as needing special treatment can be reduced by talking understandably about differences, accepting the differences as a natural part of being human and what differences mean for students' education, and emphasising the benefits of differentiation (see e.g. Kaufman \& Badar, 2013).

Next, we will carry on with our inquiry and examine the pedagogical actions and teacher competence related to the third UDL principle, called multiple means of action and expression.

\section{The Teachers Enable Their Pupils'Actions by Managing Their Teaching Through Multi-professional Team}

The third principle of the UDL model is called multiple means of action and expression. This principle deals with 'the how of learning' and focuses on providing options for physical action, expression and communication and executive functions. The goal is to support all students to becoming strategic and goal-directed learners (Rose et al., 2014), which is a principle of inclusive pedagogy, too (Florian \& Spratt, 2013). When accessing the learning process, the teacher utilises various ways, materials and techniques of communication and expression. When internalising, building one's own knowledge, the students must be conscious of the meanings of goal setting, planning, choosing of strategy and monitoring the whole learning process (CAST, 2018). 
In terms of supporting all the pupils, it was significant that there were several adults in the classroom. It was easier to utilise various ways, materials and techniques of communication and expression when there were many instructors in the class. Some pupils, for example, had difficulties in starting to work, and then a teacher or an assistant could help the pupil and direct him/her forward immediately (Observation, 8 Nov 2019).

Every week the co-teachers wrote a plan for the week into a folder, where the TA:s could see them, too. The plan included weekly learning tasks in different subjects as well as the pupils' therapies or visits to the doctor, for example. The division of work between the adults in the class was clear, and the TA:s felt that their skills were respected, as one of the TA:s pondered:

What matters to me is our team. We work together and flexibly hop into the other's shoes, if needed. - And especially we all can use our own strengths: where someone is good at, she can take care of it. I think the other [assistants of the school] are jealous while we have a chance to work in this class. (TA in mentoring discussion, 12 Oct 2017)

The co-teachers, the TA:s formed a strong multi-professional community each with their own knowledge and skills. The co-teachers and TA:s had both systematic and spontaneous discussions in which they communicated and shared their ideas, skills and knowledge (Observation, co-teachers' class, 12 Oct 2017).

The co-teachers followed the curriculum but used no study books. All the pupils got their own portfolios, which were built gradually when different learning tasks were accomplished. Six times during the school year, they received a new portfolio. Some examples of the portfolios and exercises are shown in Pictures 10.4, 10.5 and 10.6. Within each portfolio, the co-teachers enclosed a short evaluation of the pupil's progress in learning. The parents also wrote their evaluation of their child's learning from the home aspect in the portfolios.

During lessons, the co-teachers created and allowed for various ways of practising and learning. Their planning of the learning situations was based on the knowledge of their pupils, as the following examples show. The teachers were aware of
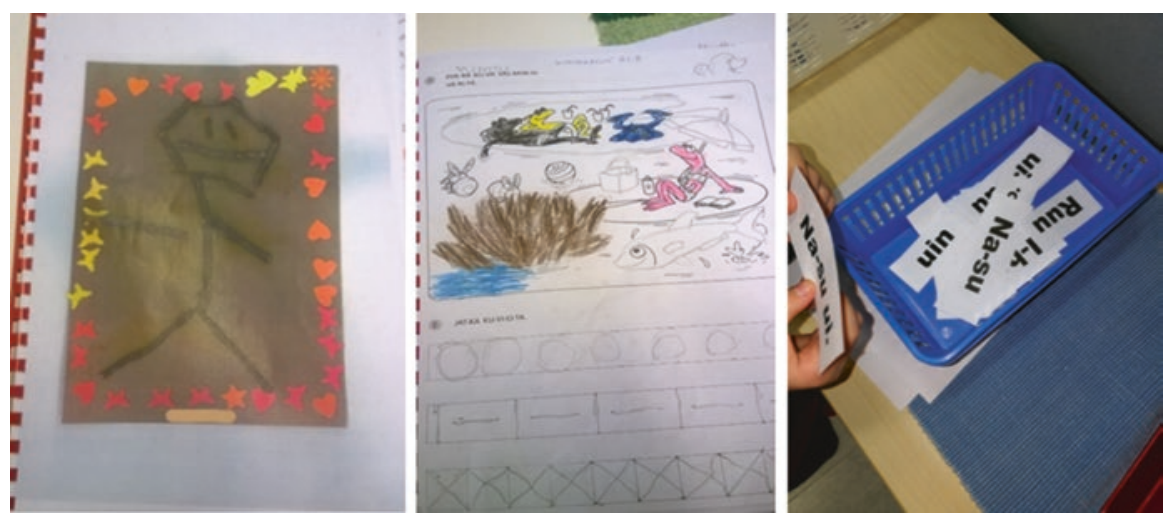

Pictures 10.4, 10.5 and 10.6 Co-teachers' pupil's own portfolio and exercises 
the children's common psychological development process and the usual difficulties in it, so they could implement theory into practice and see the possible challenges during school days. They also allowed the pupils to decide on the task or the way of practising by themselves. The pupils watched videos, read, discussed, modelled and drew and then introduced the outcomes to the others (Observation, 8 Nov 2019).

Everyone had the opportunity to bring out what they learned in their group's presentation [UDL period, Lappish animals] in a way that was pleasing to him/her and felt most comfortable. The opportunity to present in peace was also given to those whose output was slower than others, for example in reading and moving. The [talented] pupils are enabled to go at their own pace while giving the others precise instructions. (Observation, coteacher's and first grade teacher's pupils, 8 Nov 2019)

After starting to apply UDL, the pupils were allowed to construct their own learning situations. It was challenging for some, and they sometimes made decisions based on reasons other than their own competence, such as they just followed their schoolmates. In that case, they perhaps had difficulties in completing the task alone, and the adults guided those pupils towards appropriate tasks. The teachers thought that if the pupils' executive functions are still at a low level, the pupil needs more guidance.

The co-teacher 1 (special needs teacher) and the teaching assistant, having become wiser from the previous lesson, adapted the assignments and the subject to be taught to be more suitable for the special needs pupils. This time the topic was presented with more help from the teacher. (Co-teacher's and first grade teacher's notes, 24 Jan 2019)

They were either taught by scaffolding lower-level skills so that the pupils required less executive processing or by scaffolding higher-level executive skills and strategies. In addition to the meta-cognitive skills, the co-teachers also tried to promote the pupils' social skills and skills in group work.

Co-teacher 1: The pupils with SEN wanted to work in pairs, too, but they did not know how. The kids didn't understand what it means to work together, and it became an obstacle to learning. Recently, we have been practising working in pairs [...]

Co-teacher 2: Yeah, the pair work kind of works, but if we have a task that includes talking, there are a few really clever pupils who can easily dominate others. [...] This is a skill that needs to be developed, that everyone listens to each other. (Co-teachers in mentoring discussion, 7 May 2019)

For the analysis of the pupils' experiences, the co-teachers' pupils answered a survey (Aro et al. 2014) where they were asked to assess if they get help when needed, if they are encouraged and if the teachers are just/fair to them. The pupils (year $2018-N=15$, year $2019-N=14$ ) answered the propositions by assessing them with a Likert scale, which we reduced from 5 to 3 . The answers show that in 2018, most of the pupils felt that they got the support they needed. In 2019, the situation was even better. All the co-teachers' pupils answered that they got help always or often when asking for it. Furthermore, the number of the most negative answers was decreased in all three statements from 2018 to 2019. The answers are illustrated in Table 10.3. 
Table 10.3 Co-teachers pupils' answers about whether they get help, encouragement and fairness in their class

\begin{tabular}{l|l|l|l|l|l}
\hline Statement & Year & Always/often & Sometimes & Very seldom/never & $\sum$ \\
\hline \multirow{3}{*}{ I get help if I ask for it. } & 2018 & $80.0 \%(12)$ & $13.3(2)$ & $6.7 \%(1)$ & $100.0 \%(15)$ \\
\cline { 2 - 6 } & 2019 & $100.0 \%(14)$ & - & - & $100.0 \%(14)$ \\
\hline I am encouraged. & 2018 & $66.7 \%(10)$ & $13.3 \%(2)$ & $20.0 \%(3)$ & $100.0 \%(15)$ \\
\cline { 2 - 6 } & 2019 & $64.3 \%(9)$ & $28.6 \%(4)$ & $7.1 \%(1)$ & $100.0 \%(14)$ \\
\hline The teachers are fair to me. & 2018 & $86.6 \%(13)$ & - & $13.4 \%(2)$ & $100.0 \%(15)$ \\
\cline { 2 - 6 } & 2019 & $78.4 \%(11)$ & $14.4 \%(2)$ & $7.2 \%(1)$ & $100.0 \%(14)$ \\
\hline
\end{tabular}

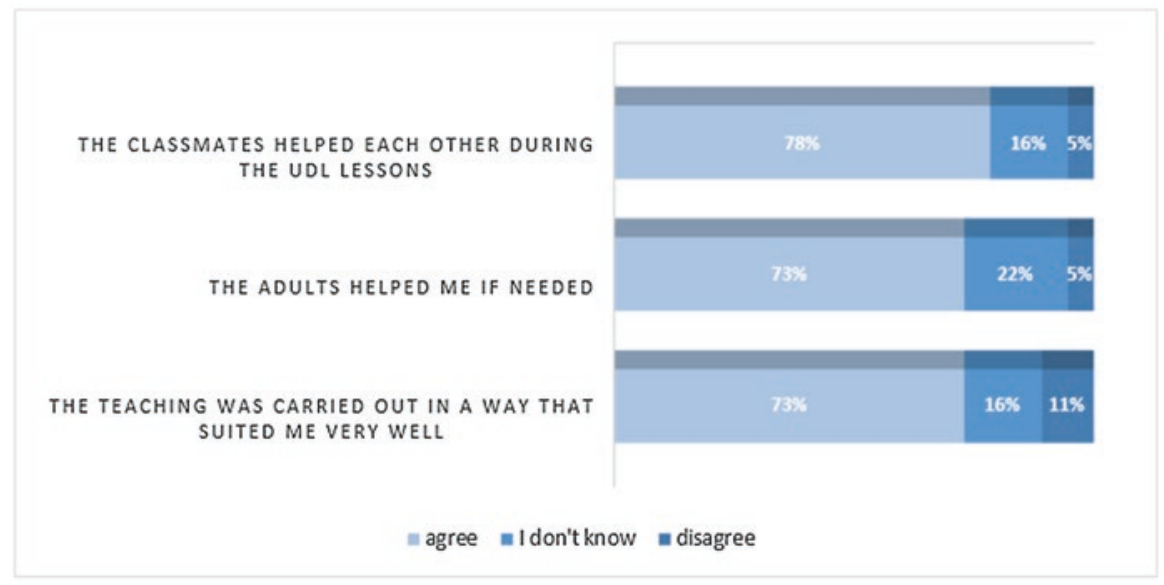

Fig. 10.8 Co-teacher's and first grade teacher's pupils' self-assessment of the teaching and support after the UDL lessons

When studying the results more explicitly, we did not find any statistically significant differences when analysing the data with Pearson's correlation (see Table 10.4 in Appendix 10.2).

After the actual UDL lessons in autumn 2019, the pupils from grade 1 and the co-teachers' third-graders $(N=37)$ took the survey 'This is what I am as a learner', assessing their own experiences of the UDL lessons (Appendix 10.1). During analysis, we combined the original five categories into three categories. The results are illustrated in Fig. 10.8.

We can see in Fig. 10.8 the pupils' positive attitude towards the teaching and support. When analysing the correlative connection with Pearson's correlation between the grade level or the support level and the answers, no statistically significant differences were found (see Table 10.5, Appendix 10.2). Even when researching the answers individually, differences between the grade level or the support level and the answers could not be found; the most negative answers in the questionnaire were given by two pupils, one first-grader with general support and one third-grader with special support. Instead, the correlation between the appropriateness of teaching and how well pupils perceived adults in helping them was statistically significant 
$\left(r=0.509^{* *}, p=0.001\right)$. In that sense, we can assume that the adults' help and support are very meaningful in the learning process.

Teacher Competence and Multiple Means of Action and Expression In this section, we utilise the MAP model to see what kind of teacher competence is needed when applying the UDL principle of multiple means of action and expression.

The multiple means of action and expression exemplifies the importance of a thorough command over the knowledge concerning the whole teaching and learning process which is interlinked with the dimension of knowledge base for teaching and learning of the MAP model. The dimension includes sub-dimensions of content knowledge, pedagogical knowledge, pedagogical content knowledge, practical knowledge and contextual knowledge, and it is seen to form the prime knowledge base for teaching (see also Shulman, 1987). The more structured the knowledge base for teaching and learning a teacher has, the more effortlessly she/he is able to apply it in different learning situations and in a heterogeneous classroom. The teachers had high expectations for all learners' achievements. According the principles of the UDL, instead of concentrating on learning obstacles, the teachers promoted the academic, practical, social and emotional learning of all learners (CAST, 2018). They asked their pupils to explain their answers to make sure the pupil had a good understanding of the concept. In addition, the communication enabled the other pupils to learn from each other's expressions.

The skills of reflection, creativity and clear communication resonate with the teachers' cognitive thinking skills of the MAP model (Metsäpelto et al., 2020). This dimension consists of five sub-dimensions, which are information processing, critical thinking and problem-solving, creativity, communication including argumentation and reasoning, and metacognition. In our research, the teachers' reflection in one's teaching developed their pedagogical actions. Teachers' reflection skills are underscored in many documents, such as in the Principles for Teacher Education in Europe (European Commission, 2005). Moreover, in the Profile of Inclusive Teachers, the value of personal professional development is mentioned (European Agency for Development in Special Needs Education, 2012). We can consider the teachers as reflective practitioners who think critically and solve problems by examining ideas, analysing arguments and synthesising information in order to modify the action and expression appropriate to the pupils (Binkley et al., 2012; Bagnato et al., 2013).

In the MAP model, the social skills contain four sub-categories. They are relational skills, emotional competence, diversity competence and intercultural competence, and they are all emphasised in the co-teachers and TA:s' pedagogical practices and activities of our research class. Together, the teachers and TA:s worked sensitively and with attitudes which prevented unequal treatment and marginalisation processes in the classroom community and promoted responses to individual differences in learning in ways that support and respect the dignity of each pupil (cf. Booth \& Ainscow, 2011; Spratt \& Florian, 2015). The awareness of the cultural context was especially important in our school case because the school was situated in the region of the Sámi people, an indigenous people in Finland. The teachers needed to navigate and communicate sensitively across the multicultural contexts (Bennett, 2009).

The last theme to be discussed here is the collaboration between professionals. According to Denham (2005), individuals need high-quality relational and 
emotional skills in effective collaboration. The teachers took possession of the pedagogical leadership in their small professional team in their class. There were several parts to be fit together, including efficient communication and transmission of knowledge among the teachers and TA:s (cf. Lakkala et al., 2016). In our research classes, all the professionals, with their own particular knowledge and skills, were appreciated, and all employees had possibilities to participate in the process of planning and executing the teaching.

While inclusive pedagogy breaks out of the traditional paradigm of teaching alone (see e.g. Lakkala \& Kyrö-Ämmälä, 2017), one would presume that the organisational level of pedagogical practices would be recognised in the UDL approach, too. In turn, the MAP model distinguishes three levels of pedagogical practices (Metsäpelto et al., 2020) of individual and group levels; organisation level; and local, national and global levels. When it comes to pedagogical leadership concerning inclusive pedagogies and UDL, the organisational level appears as an important level concerning the teachers' abilities to collaborate with colleagues, other professionals and parents.

In our research, the teachers were very competent in creating versatile learning environments for their pupils. Particularly, they utilized their abilities to build positive professional relationships to other professionals in order to enhance their pupils' learning and well-being. In this respect, our action research did not bring any new elements to teachers' pedagogy. However, the reflection with researchers on the applied practices raised the teachers' awareness of their situation specific skills and the competence behind them (Metsäpelto et al., 2020).

\subsection{Discussion and Conclusions}

In this chapter, we summarise the research results within the theoretical frames. Here, we reach the last phase of our action research. We distance ourselves from the practice and look at teachers' actions through theoretical lenses. We present the teacher competence that is required in the teaching process when applying UDL principles based on our research.

In our research results, we have focused on the most evident features of teacher competence that need to be involved especially when implementing the UDL approach in the context of inclusive education. In the results section, we introduced our data by presenting a few examples of teachers' everyday situations, where they observed, interpreted and made decisions that fit the time, place and context of their own class (Braun \& Clarke, 2006). By analysing the everyday situations, we could identify the teachers' situation-specific skills (Metsäpelto et al., 2020) that can be paralleled to certain teacher competencies. We summarise the results of our analysis in Fig. 10.9.

Based on our analysis, the most wide-reaching dimension of teacher competence seems to be the teacher's cognitive thinking skills, which were interlinked to all three principles of UDL. The dimension is placed in the middle of Fig. 10.9. When implementing UDL, the teacher needs to be a reflective practitioner (Jay \& Johnson, 2002) who evaluates his/her actions all the time and learns through and from the experiences, at the same time expanding new insights into the teaching profession 


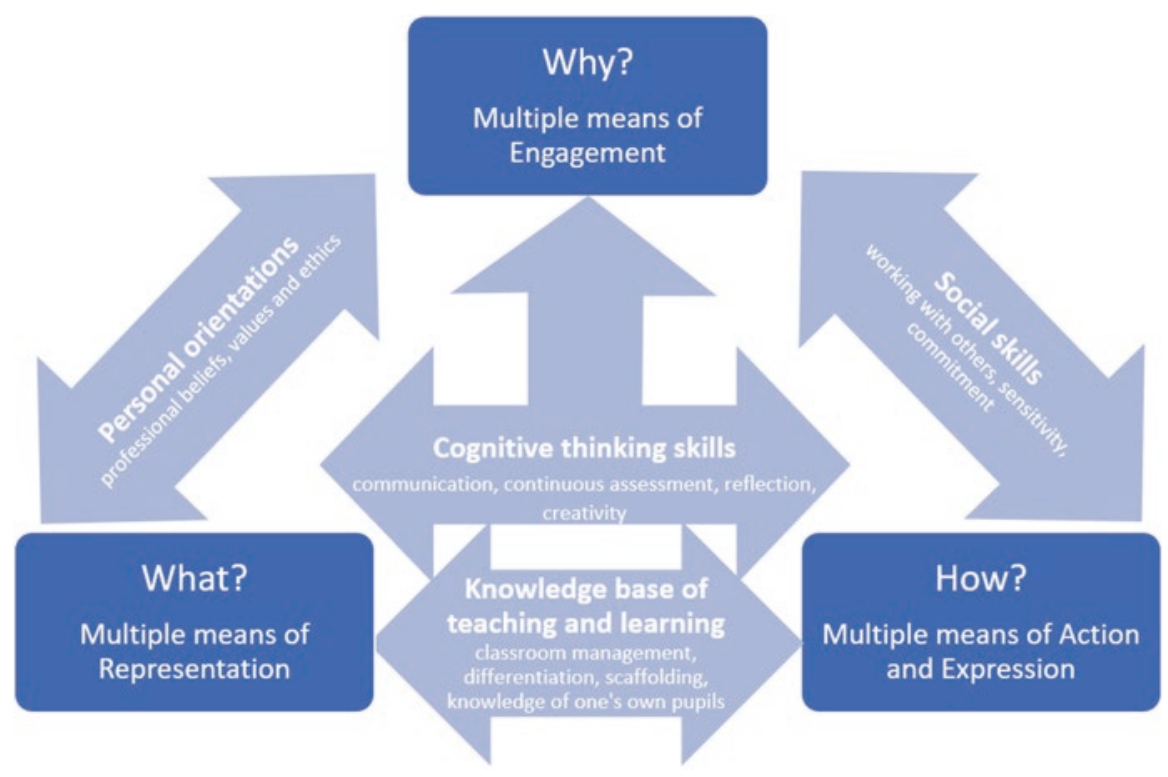

Fig. 10.9 Teacher competence required when applying UDL principles

and practice (Finlay, 2008). Furthermore, teachers' reflection and meta-cognitive skills are crucial because students benefit when teachers know how to teach metacognitive skills and self-assessment (see e.g. Annevirta et al., 2007). Cognitive thinking skills also involve communication skills. In a high-quality learning situation, the teacher is expected to communicate and articulate thoughts and ideas precisely and express arguments in a believable way (Deardorff, 2006).

On the left side of Fig. 10.9, we placed the dimension of teacher competence called teacher's personal orientation. Teachers' professional beliefs, values and ethics guide the decisions that they make in everyday situations (Metsäpelto et al., 2020). When examining the UDL principle called multiple means of engagement, the teacher's commitment to and responsibility for pupils and their learning came to the fore in our results. In inclusive education, teachers trust that all children can learn, that they are worth of education and that the teachers have the capacity to make the difference (Rouse, 2010; Florian \& Spratt, 2013). A teacher with values that include a strong commitment to every child's right to a safe learning environment is likely to take care of students' well-being in the classroom (Metsäpelto et al., 2020). In addition, we linked the teachers' personal orientation to the UDL principle called multiple means of representation, where, while reducing barriers to learning, the teacher needs to get closely acquainted with the problems of each learner (Rose et al., 2014).

The dimension of teacher competence called teacher's social skills we positioned to the right side of Fig. 10.9. The teacher's ability to enhance pupils' sense of belonging and the cohesion of the heterogeneous group are important in engaging the students with their social community and studies. A sense of belonging and a positive and warm class atmosphere are significant prerequisites to pupils' well-being and quality of learning 
(Pakarinen et al., 2010). They are seen as key elements of inclusive education (Bossaert et al., 2013). According to our previous research (Lakkala \& Kyrö-Ämmälä, 2017), the collaboration between co-teachers, parents and other professionals is at the heart of inclusive education. The ability to manage classroom with the help of colleagues makes applying the multiple means of action and expression easier. Through collaboration, it is possible to construct a system of flexible support for pupils' learning processes. This way, teachers' solid social and communication skills are also important in interactions with adults (see e.g. Lakkala \& Kyrö-Ämmälä, 2017).

The last dimension of teacher competence in Fig. 10.9 is the teacher's knowledge base for teaching and learning, which we placed at the bottom of the figure, in the middle of the 'what' of learning and the 'how' of learning. Teachers' knowledge base for teaching and learning is connected to the UDL principles of multiple means of representation as well as multiple means of action and expression. When teaching diverse pupils, the teacher utilises multiple ways of teaching and amends the curriculum, which requires an excellent knowledge of the subject matter (Tomlinson, 1999). In our research, teachers' knowledge base for teaching and learning included the following three sub-dimensions: (1) content knowledge, which indicates the teacher's expertise in the subject matter and refers to domain-specific knowledge (e.g. facts, concepts, phenomena) but also the teacher's understanding of the curricular content to be taught (Shulman, 1987; Baumert \& Kunter, 2013); (2) pedagogical knowledge, with which the teacher manages the classroom, implements the learning theories in practice and promotes pupils' learning processes (Shulman, 1987; Guerriero \& Révai, 2017); and (3) pedagogical content knowledge, which is the combination of expertise in subject matter (content) and pedagogical competence (teaching) (Kuusisto \& Tirri, 2014).

Discussion Our research aim was to view the teachers' pedagogical practices in implementing the UDL model in the theoretical context of the MAP model of teaching (Metsäpelto et al., 2020). We studied the teacher competence needed when implementing UDL in the context of inclusive education in two heterogeneous classes. The main research question was to find out what kind of competence do the teachers need when they teach using the UDL approach? The research classes and their teachers were selected as a case for our research by the initiative of the teachers themselves. The teachers' co-operation took off while the special education teacher experienced loneliness when her special needs class was isolated from others. The teachers wanted to develop inclusive education utilising research-based knowledge. The teachers own willingness to develop as professionals gave us a great opportunity to carry out an action research process with them. After the co-teachers felt that they had adopted new insights in their teaching, they pursued to try out UDL principles in a larger scale. Therefore, the co-teachers invited a third teacher and her class to join the UDL lessons. Consequently, when examining the reliability and especially generalisability of our research, it should be noted that the results of the action research were built on the actions of very motivated and skilled teachers.

In some respect, the co-teachers' class was not a typical Finnish classroom. To begin with, there were atypically many adults at the classroom - two teachers and several TA:s. Furthermore, the group was unusually heterogeneous as besides the pupils with no special needs, there were many pupils with special educational needs. 
The third exceptional feature in the co-teachers' class was that they did not use any study books; rather, they, with their TA:s, created the learning material by themselves from the basis of their pupils' needs, amending the curriculum.

Next, we will consider the UDL approach in wider contextual frame. When analysing the teachers' pedagogical practices, we noticed that the UDL approach concentrates almost only on the individual and group levels of teaching, ignoring the organisational, local, national and global levels, which, in turn, are considered in the MAP model. On the one hand, in many investigations, teacher effectiveness is often defined through the quality of the classroom processes, such as how to organise optimal learning environments and how to support learning processes (cf. Ball et al., 2009). But on the other hand, by concentrating on teaching at the individual and group levels, a meaningful part of the teacher's profession is ignored. Nowadays, a teacher is seen as a co-worker who acts in multiagency teams with other professionals and parents (Watkins \& Donnelly, 2012; Florian \& Spratt, 2013; Lakkala \& Kyrö-Ämmälä, 2017). For example, in our research class, the co-teachers' collaboration with parents increased the parents' commitment to their children's schoolwork. The collaboration reflected positively on the classroom atmosphere and the pupils' outcomes. In addition, when the parents showed their appreciation towards the teachers' work, it had a positive influence on the teachers' well-being as well.

To continue on the subject, while the striving towards inclusive education has transformed the position of the teacher from a lone-worker to a co-worker, it has become very clear that inclusive education cannot be carried out by single teachers (see e.g. Lakkala \& Kyrö-Ämmälä, 2017). On the contrary, many researchers and scholars argue that inclusive education is a whole-school or even a state-wide issue (see e.g. Hargreaves \& Shirley, 2009; Jahnukainen, 2015). While inclusive education requires collaboration and a common strategy on the institutional level (Booth \& Ainscow, 2011), a single teacher does not have the power of creating conditions where all learners' equal learning possibilities may take place. Another problem arises from the nature of inclusive education. When the learners' needs are responded to, flexible and transformable solutions are needed. Flexibility at the institutional level demands forums of discussion and collaboration for the professionals in schools (Lakkala et al., 2016). From the perspective of inclusive education, it can be problematic that institutions tend to 'finish' their procedures and may appear inflexible, holding on to the established education system (cf. Haustätter Sarromaa, 2014).

As stated above, the wider educational context, like the dominating learning concepts, have an effect on the pedagogical practices at the individual and group levels. In our case, the teaching of teachers can be characterised following the socio-constructivist learning conception. The roots of socio-constructivism go back to the theories of Piaget, Vygotsky and Dewey, but its influence on teaching has grown since the 1980s. Socioconstructivism implies that learners are encouraged to construct their own knowledge in realistic situations together with others, instead of copying it from an authority (Vygotsky, 1978; Kugelmass, 2007). The pupils construct the new knowledge upon the foundation of previous knowledge and experience; thus, the teacher has to be very well aware of the pupil's present structure of knowledge. In our research, the co-teachers' excellent knowledge about their pupils enabled them to amend their teaching and the learning environment according to their pupils' needs and strengths. 
Finnish educational policies have their impact on the teachers' pedagogical actions in our case study. In Finland, teachers have a high degree of professional autonomy regarding the implementation of the curriculum. Finnish teachers have many opportunities to influence and develop their work. They can, among others, determine the teaching methods, learning materials and assessment strategies they use in their teaching (Sahlberg, 2010; Ministry of Education and Culture, 2016). Moreover, the Finnish Core Curriculum emphasises the meaning of assessment in terms of promoting and encouraging the student's learning process (FNAE, 2016). Thus, Finnish teachers are trained to pay attention to supporting their students' concepts of themselves as capable learners. Therefore, the national official norm probably guided the teachers in our research to apply positive feedback in their teaching as a rule. In addition, all Finnish teachers in comprehensive schools have master'slevel teacher education, which enables them to utilise their research-based education in different ways (cf. Ministry of Education and Culture, 2016).

The last phase in the chart of the MAP model accentuates pupils' learning, motivation and well-being (Metsäpelto et al., 2020). In our research, we explored pupils' experiences of their studies by self-assessment via the surveys 'I as a schoolchild' (Aro et al., 2014), 'I as a learner' and sociometric measures. Although the survey 'I as a schoolchild' was delivered before and after the first UDL trials, no clear changes could be detected. However, the measurements gave a very positive impression about how the co-teachers' pupils felt about themselves as learners and schoolchildren. On the other hand, the measures also revealed negative attitudes, and often these were pupils with SEN. When interpreting the answers at the individual level, attention can be paid to the possibility that some child has a tendency of answering negatively, but the negative response can also reflect the real experience of the child (Aro et al., 2014). Yet, the results of the sociometric measurement revealed that the co-teachers' pupils had grown to appreciate each other's help in study tasks, but during the breaks, they were not willing to play with classmates who were bossy and cranky. The same kinds of results have been detected in previous research as well. Students with behavioural problems are the most rejected in school communities from both teachers and students (see e.g. Dodge et al., 2003).

Nevertheless, during our action research process, we could follow remarkable progress in many pupils' lives. For example, the pupil who was rejected by the other children in informal situations developed his social skills and started to trust that he could learn and that he was being cared for at school. Furthermore, this pupil's parents began to trust the teachers' good will and appreciation towards their son. After that, they were able to negotiate about the pupil's problems in a good spirit. The individual narratives show that respecting and caring for children enable confidential relationships to be established which, in turn, bear fruit in many ways.

As further research, it would be interesting to examine the adoption of the UDL approach and teachers' professional competence during teacher education, such as how to promote student teachers' competence in light of inclusive education. Research could also focus on the intentional formation of student teachers' professional identities as teaching practices seem to be based on the teacher's identity, attitudes and values (cf. Levin \& He, 2008). 


\section{Appendices}

Appendix 10.1: 'This Is What I Am as a Learner' Self-Assessment Form

\section{THIS IS WHAT I AM AS A LEARNER}

Evaluate your own work during the UDL lessons. From each line, choose the emoticon that best describes your own experience.

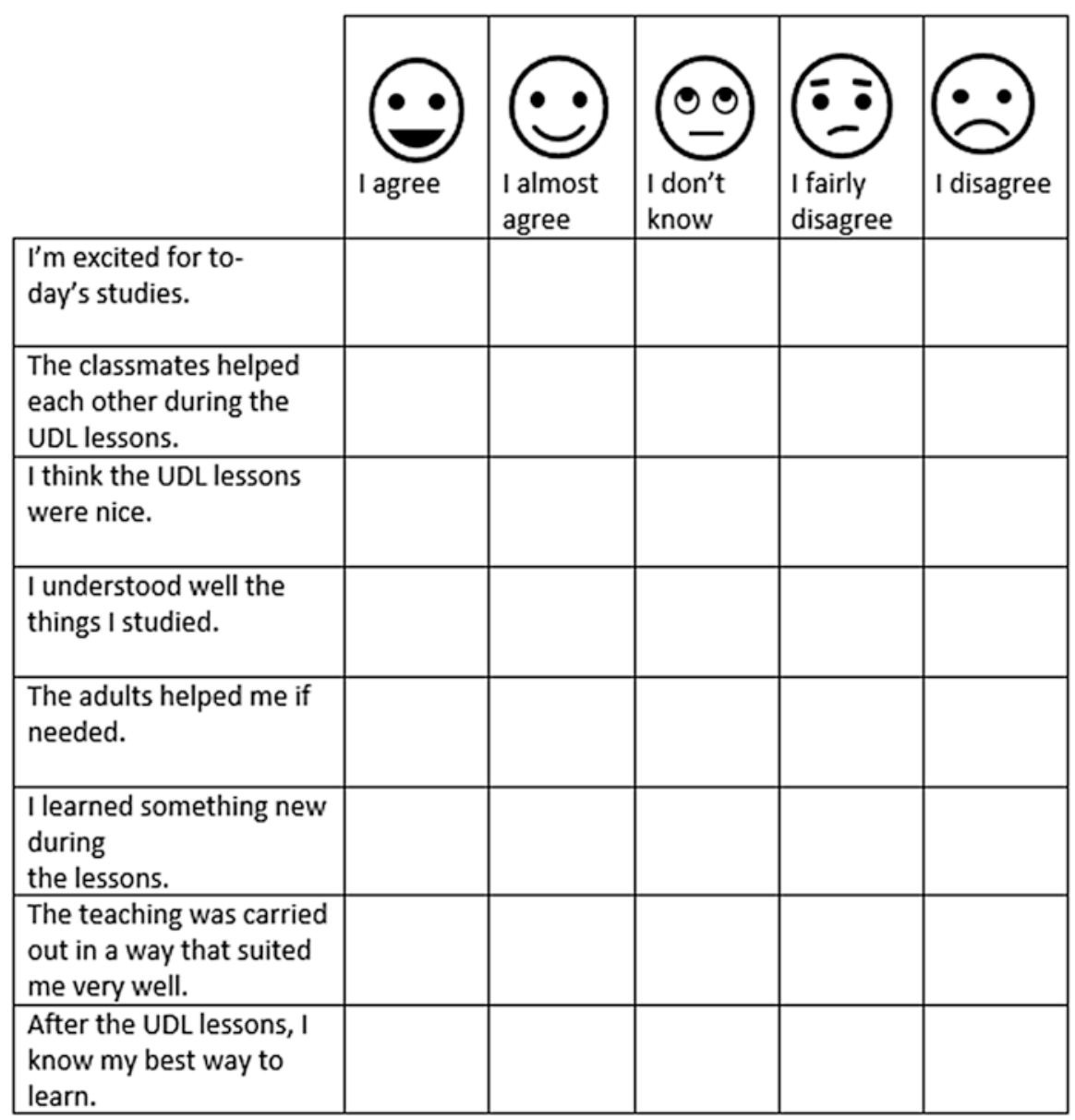




\section{Appendix 10.2: The Tables of Correlation (Tables 10.2, 10.4 and 10.5)}

Table 10.2 Correlation between support level and pupils' experience of the UDL lessons

\begin{tabular}{l|l|l|l|l|l}
\hline \multicolumn{2}{l}{} & $\begin{array}{l}\text { Support } \\
\text { level }\end{array}$ & $\begin{array}{l}\text { An enthusiastic } \\
\text { learner }\end{array}$ & $\begin{array}{l}\text { Good } \\
\text { understanding }\end{array}$ & $\begin{array}{l}\text { Learned } \\
\text { something new }\end{array}$ \\
\hline \multirow{2}{*}{ Support level } & $\begin{array}{l}\text { Pearson } \\
\text { correlation }\end{array}$ & 1 & 0.000 & 0.079 & 0.000 \\
\cline { 2 - 6 } & Sig. (2-tailed) & & 1.000 & 0.643 & 1.000 \\
\cline { 2 - 6 } & $N$ & 38 & 37 & 37 & 36 \\
\hline \multirow{2}{*}{$\begin{array}{l}\text { An enthusiastic } \\
\text { learner }\end{array}$} & $\begin{array}{l}\text { Pearson } \\
\text { correlation }\end{array}$ & & 1 & 0.211 & $0.356^{*}$ \\
\cline { 2 - 6 } & Sig. (2-tailed) & & & 0.209 & 0.033 \\
\cline { 2 - 6 } & $N$ & & 37 & 37 & 36 \\
\hline \multirow{2}{*}{$\begin{array}{l}\text { Good } \\
\text { understanding }\end{array}$} & $\begin{array}{l}\text { Pearson } \\
\text { correlation }\end{array}$ & & & 1 & 0.312 \\
\cline { 2 - 6 } & Sig. (2-tailed) & & & & 0.064 \\
\cline { 2 - 6 } & $N$ & & & & 36 \\
\hline \multirow{2}{*}{$\begin{array}{l}\text { Learned } \\
\text { something new }\end{array}$} & $\begin{array}{l}\text { Pearson } \\
\text { correlation }\end{array}$ & & & & 1 \\
\cline { 2 - 6 } & Sig. (2-tailed) & & & & 36 \\
\cline { 2 - 6 } & $N$ & & & & \\
\hline
\end{tabular}

*Correlation is significant at the 0.05 lever (2-tailed)

Table 10.4 Correlation between support level and pupils' experience of assistance, encouragement and justice (2018 and 2019)

\begin{tabular}{l|l|l|l|l|l|l|l}
\hline \multicolumn{2}{l|}{} & $\begin{array}{l}\text { Access to } \\
\text { assistance } \\
2018\end{array}$ & $\begin{array}{l}\text { Access to } \\
\text { assistance } \\
2019\end{array}$ & $\begin{array}{l}\text { Encoura } \\
\text { gement } \\
2018\end{array}$ & $\begin{array}{l}\text { Encoura } \\
\text { gement } \\
2019\end{array}$ & $\begin{array}{l}\text { Fair } \\
\text { teachers } \\
2018\end{array}$ & $\begin{array}{l}\text { Fair } \\
\text { teachers } \\
2019\end{array}$ \\
\hline \multirow{2}{*}{ Support level } & $\begin{array}{l}\text { Pearson } \\
\text { correlation }\end{array}$ & 0.095 & -0.125 & -0.037 & 0.301 & 0.386 & 0.229 \\
\cline { 2 - 9 } & Sig. (2-tailed) & 0.737 & 0.0670 & 0.897 & 0.295 & 0.156 & 0.431 \\
\cline { 2 - 9 } & $N$ & 15 & 14 & 15 & 14 & 15 & 14 \\
\hline
\end{tabular}


Table 10.5 Correlation between support level/grade level and experience of assistance or suitability of lessons after the UDL lessons

\begin{tabular}{|c|c|c|c|c|c|c|}
\hline & & $\begin{array}{l}\text { Support } \\
\text { level }\end{array}$ & $\begin{array}{l}\text { Grade } \\
\text { level }\end{array}$ & $\begin{array}{l}\text { Help from } \\
\text { classmates }\end{array}$ & $\begin{array}{l}\text { Help from } \\
\text { adults }\end{array}$ & $\begin{array}{l}\text { Appropriate } \\
\text { lesson }\end{array}$ \\
\hline \multirow[t]{3}{*}{ Support level } & $\begin{array}{l}\text { Pearson } \\
\text { correlation }\end{array}$ & 1 & $0.510^{* *}$ & 0.009 & -0.003 & -0.099 \\
\hline & \begin{tabular}{|l|} 
Sig. \\
(2-tailed)
\end{tabular} & & 0.001 & 0.958 & 0.985 & 0.560 \\
\hline & $N$ & 38 & 38 & 37 & 37 & 37 \\
\hline \multirow[t]{3}{*}{ Grade level } & $\begin{array}{l}\text { Pearson } \\
\text { correlation }\end{array}$ & & 1 & 0.046 & -0.121 & -0.085 \\
\hline & \begin{tabular}{|l|} 
Sig. \\
(2-tailed)
\end{tabular} & & & 0.785 & 0.146 & 0.616 \\
\hline & $N$ & & 38 & 37 & 37 & 37 \\
\hline \multirow[t]{3}{*}{$\begin{array}{l}\text { Help from } \\
\text { classmates }\end{array}$} & $\begin{array}{l}\text { Pearson } \\
\text { correlation }\end{array}$ & & & 1 & $0.364^{*}$ & 0.157 \\
\hline & \begin{tabular}{|l|} 
Sig. \\
(2-tailed)
\end{tabular} & & & & 0.027 & 0.354 \\
\hline & $N$ & & & 37 & 37 & 37 \\
\hline \multirow[t]{3}{*}{$\begin{array}{l}\text { Help from } \\
\text { adults }\end{array}$} & \begin{tabular}{|l} 
Pearson \\
correlation
\end{tabular} & & & & 1 & $0.509 * *$ \\
\hline & \begin{tabular}{|l} 
Sig. \\
(2-tailed)
\end{tabular} & & & & & 0.001 \\
\hline & $N$ & & & & 37 & 37 \\
\hline \multirow[t]{3}{*}{$\begin{array}{l}\text { Appropriate } \\
\text { lesson }\end{array}$} & \begin{tabular}{|l|}
$\begin{array}{l}\text { Pearson } \\
\text { correlation }\end{array}$ \\
\end{tabular} & & & & & 1 \\
\hline & \begin{tabular}{|l|} 
Sig. \\
(2-tailed)
\end{tabular} & & & & & \\
\hline & $N$ & & & & & 37 \\
\hline
\end{tabular}

**Correlation is significant at the 0.01 level (2-tailed)

*Correlation is significant at the 0.05 level (2-tailed)

\section{References}

Annevirta, T., Laakkonen, E., Kinnunen, R., \& Vauras, M. (2007). Developmental dynamics of metacognitive knowledge and text comprehension skill in the first primary school years. Metacognition and Learning, 2, 21-39. https://doi.org/10.1007/s11409-007-9005-x.

Aro, T., Järviluoma, E., Mäntylä, M., Mäntynen, H., Määttä, S., \& Paananen, M. (2014). Oppilaan minäkuva ja luottamus omiin kykyihin. Arviointi-, opetus- ja kuntoutusmateriaaleja [Student's self-image and confidence on person's own competence. Evaluation, teaching and rehabilitation materials]. Jyväskylä: Niilo Mäki Instituutti.

Bagnato, S., Dimonte, V., \& Garrino, L. (2013). The reflective journal: A tool for enhancing experience-based learning in nursing students in clinical practice. Journal of Nursing Education and Practice, 3(3). 
Ball, D., Sleep, L., Boerst, T., \& Bass, H. (2009). Combining the development of practice and the practice of development in teacher education. Elementary School Journal, 109, 458-474. https://doi.org/10.1086/596996.

Baumert, J., \& Kunter, M. (2013). The COACTIV model of teachers' professional competence. In M. Kunter, J. Baumert, W. Blum, U. Klusmann, S. Krauss, \& M. Neubrand (Eds.), Cognitive activation in the mathematics classroom and professional competence of teachers: Results from the COACTIV Project. New York: Springer.

Bennett, M. (2009). Defining, measuring, and facilitating intercultural learning: A conceptual introduction to the intercultural education double supplement. Intercultural Education, 20, 1-13. https://doi.org/10.1080/14675980903370763.

Binkley, M., Erstad, O., Herman, J., Raizen, S., Ripley, M., Miller-Ricci, M., \& Rumble, M. (2012). Defining twenty-first century skills. In P. Griffin, B. McGaw, \& E. Care (Eds.), Assessment and teaching of 21st century skills (pp. 17-66). Dordrecht: Springer.

Blömeke, S., Gustafsson, J. E., \& Shavelson, R. J. (2015). Beyond dichotomies: Competence viewed as a continuum. Zeitschrift für Psychologie, 223, 3-13.

Booth, T., \& Ainscow, M. (2011). Index for inclusion: Developing learning and participation in schools. Bristol: Centre for Studies in Inclusive Education.

Bossaert, G., Colpin, H., Pijl, S. J., \& Petry, K. (2013). Truly included? A literature study focusing on the social dimension of inclusion in education. International Journal of Inclusive Education, 17(1), 60-79. https://doi.org/10.1080/13603116.2011.580464.

Braun, V., \& Clarke, V. (2006). Using thematic analysis in psychology. Qualitative Research in Psychology, 3(2), 77-101. https://doi.org/10.1191/1478088706qp063oa.

Brydon-Miller, M., Greenwood, D., \& Maguire, P. (2003). Why action research? Action Research, 1(1), 9-28. London: Sage.

Burke, J., \& Claughton, A. (2019). Playing with or next to? The nuanced and complex play of children with impairments. International Journal of Inclusive Education, 23(10), 1065-1080. https://doi.org/10.1080/13603116.2019.1626498.

Buyse, E., Verschueren, K., Doumen, S., Van Damme, J., \& Maes, F. (2008). Classroom problem behavior and teacher-child relationships in kindergarten: The moderating role of classroom climate. Journal of School Psychology, 46(4), 367-391.

CAST. (2018). Universal design for learning guidelines version 2.2. http://udlguidelines.cast.org. Accessed 2 Nov 2020.

Cohen, L., Manion, L., \& Morrison, K. (2011). Research methods in education (7th ed.). London: Routledge.

Deardorff, D. (2006). Identification and assessment of intercultural competence as a student outcome of internationalization. Journal of Studies in International Education, 10, 241-266. https://doi.org/10.1177/1028315306287002.

Denham, S. A. (2005). Assessing social-emotional development in children from a longitudinal perspective for the National Children's Study: Social-emotional compendium of measures. Fairfax: George Mason University.

Dodge, K. A., Lansford, J. E., Salzer Burks, V., Bates, J. E., Pettit, G. S., Fontaine, R., \& Price, J. M. (2003). Peer rejection and social information-processing factors in the development of aggressive behavior problems in children. Child Development, 74(2), 374-393.

Elder, A. D. (2010). Children's self-assessment of their school work in elementary school. Education, 3-13, 38(1), 5-11. https://doi.org/10.1080/03004270802602044.

European Agency for Development in Special Needs Education. (2012). Teacher education for inclusion: Profile of inclusive teachers. https://www.european-agency.org/sites/default/files/ profile_of_inclusive_teachers_en.pdf. Accessed 15 Sept 2020.

European Commission. (2005). Common European principles for teacher competence and qualifications. Education and culture. Lifelong learning: Education and training policies, School education and higher education. http://www.pef.uni-lj.si/bologna/dokumenti/eu-commonprinciples.pdf. Accessed 9 Nov 2020. 
Finlay, L. (2008). The reflexive journey: Mapping multiple routers. In L. Finlay \& B. Gough (Eds.), Reflexivity: A practical guide for researchers in health and social sciences (pp. 3-20). Blackwell Publishing Company.

Finnish National Board of Education. (n.d.). Finnish Education System. https://www.oph.fi/en/ education-system. Accessed 9 Nov 2020.

Florian, L., \& Black-Hawkins, K. (2011). Exploring inclusive pedagogy. British Educational Research Journal, 37(5), 813-828. https://doi.org/10.1080/01411926.2010.501096.

Florian, L., \& Spratt, J. (2013). Enacting inclusion: A framework for interrogating inclusive practice. European Journal of Special Needs Education, 28(2), 119-135. https://doi.org/10.108 0/08856257.2013.778111.

FNAE, Finnish National Agency of Education. (2016). National core curriculum for basic education 2014 (Publications 5). Helsinki: Finnish National Board of Education.

Ford, M. P. (2005). Differentiation through flexible grouping: Successfully reaching all readers. Learning Point Associates, North Central Regional Educational Laboratory.

Guerriero, S., \& Révai, N. (2017). Knowledge-based teaching and the evolution of a profession. In S. Guerriero (Ed.), Pedagogical knowledge and the changing nature of the teaching profession. Paris: OECD Publishing.

Hamre, B. K., \& Pianta, R. C. (2005). Can instructional and emotional support in the first-grade classroom make a difference for children at risk of school failure? Child Development, 76(5), 949-967.

Hamre, B. K., Pianta, R. C., Downer, J. T., DeCoster, J., Mashburn, A. J., Jones, S. M., Brown, J. L., Cappella, E., Atkins, M., Rivers, S. E., Brackett, M. A., \& Hamaga, A. (2013). Teaching through interactions: Testing a developmental framework of teacher effectiveness in over 4000 classrooms. The Elementary School Journal, 113(4), 461-487.

Hargreaves, A. (2000). Four ages of professionalism and professional learning. Teachers and Teaching: Theory and Practice, 6(2), 151-182.

Hargreaves, A., \& Shirley, D. (2009). The fourth way: The inspiring future of educational change. Thousand Oaks: Corwin.

Hausstätter Sarromaa, R. (2014). In support of unfinished inclusion. Scandinavian Journal of Educational Research, 58:4, 424-434 doi:https://doi.org/10.1080/00313831.2013.773553.

Hienonen, N., Lintuvuori, M., Jahnukainen, M., Hotulainen, R., \& Vainikainen, M.-P. (2018). The effect of class composition on cross-curricular competences - Students with special educational needs in regular classes in lower secondary education. Learning and Instruction, 58, 80-87. https://doi.org/10.1016/j.learninstruc.2018.05.005.

Jahnukainen, M. (2015). Inclusion, integration, or what? A comparative study of the school principals' perceptions of inclusive and special education in Finland and in Canada. Disability \& Society, 30(5), 59-72. https://doi.org/10.1080/09687599.2014982788.

Jay, J. K., \& Johnson, K. L. (2002). Capturing complexity: A typology of reflective practice for teacher education. Teaching and Teacher Education, 18(1), 73-85.

Jimenez, B. A., \& Hudson, M. E. (2019). Including students with severe disabilities in general education and the potential of Universal Design for Learning for all children. In M. J. Schuelka, C. J. Johnstone, G. Thomas, \& A. J. Artiles (Eds.), The Sage handbook of inclusion and diversity in education (pp. 288-306). London: Sage.

Joseph, S., Thomas, M., Simonette, G., \& Ramsook, L. (2013). The impact of differentiated instruction in a teacher education setting: Successes and challenges. International Journal of Higher Education, 2(3), 28-40. https://doi.org/10.5430/ijhe.v2n3p28.

Kaufman, J. R., \& Badar, J. (2013). How we might make special education for students with emotional or behavioral disorders less stigmatizing. Behavioral Disorders, 39(1), 16-27. https:// doi.org/10.1177/019874291303900103.

Koster, B., \& Dengerink, J. (2008). Professional standards for teacher educators: How to deal with complexity, ownership and function. Experiences from the Netherlands. European Journal of Teacher Education, 31, 135-149. https://doi.org/10.1080/02619760802000115. 
Krathwohl, D. (2002). A revision of Bloom's taxonomy: An overview. Theory Into Practice, 41(4), 212-218.

Kugelmass, J. W. (2007). Constructivist views of learning: Implications for inclusive education. In L. Florian (Ed.), The Sage handbook of special education (pp. 272-279). London: Sage.

Kurth, J. A., \& Gross, M. (2015). The inclusion toolbox. Strategies and techniques for all teachers. London: Corwin A. Sage Company.

Kuusisto, E., \& Tirri, K. (2014). The core of religious education: Finnish student teachers' pedagogical aims. Journal of Beliefs and Values, 35(2), 187-199. https://doi.org/10.1080/1361767 2.2014.953297.

Lakkala, S., \& Kyrö-Ämmälä, O. (2017). The Finnish school case. In A. Galkienė (Ed.), Inclusion in socio-educational frames: Inclusive school cases in socio-educational frames (pp. 267-309). Vilnius: The publishing house of the Lithuanian University of Educational Sciences.

Lakkala, S. P., \& Määttä, K. (2011). Toward a theoretical model of inclusive teaching strategies: An action research in an inclusive elementary class. Global Journal of Human Social Science, $11(8), 31-40$.

Lakkala, S., Uusiautti, S., Kyrö-Ämmälä, O., \& Grönfors, P. (2020). Students’ social self-image and engagement to studies - A qualitative multimethod research on teachers' pedagogical activities in inclusive education. International Journal of Whole Schooling, 16(1), 35-60.

Lakkala, S., Uusiautti, S., \& Määttä, K. (2016). How to make the neighbourhood school a school for all? Journal of Research in Special Educational Needs, 16(1), 46-56. https://doi. org/10.1111/1471-3802.12055.

Levin, B., \& He, Y. (2008). Investigating the content and sources of teacher candidates' personal practical theories. Journal of Teacher Education, 59(1), 55-68.

Lingard, B., \& Mills, M. (2007). Pedagogies making a difference: Issues of social justice and inclusion. International Journal of Inclusive Education, 11(3), 233-244.

Lumby, J., \& Coleman, M. (2016). Leading for equality. Making schools fairer. London: Sage.

Metsäpelto, R-L., Poikkeus, A-M., Heikkilä, M., Heikkinen-Jokilahti, K., Husu, J., Laine, A., Lappalainen, K., Lähteenmäki, M., Mikkilä-Erdmann, M., \& Warinowski, A. (2020). Conceptual framework of teaching quality: A multidimensional adapted process model of teaching. psyarxiv.com/52tcv, https://doi.org/10.31234/osf.io/52tcv. Accessed 3 Nov 2020.

Ministry of Education and Culture. (2016). Teacher education in Finland. https://minedu. fi/documents/1410845/4150027/Teacher+education+in+Finland/57c88304-216b-41a7ab36-7ddd4597b925. Accessed 26 Oct 2020.

Ministry of Education and Culture. (n.d.-a). Basic education. https://minedu.fi/en/basic-education. Accessed 26 Oct 2020.

Ministry of Education and Culture. (n.d.-b). Policies and development. https://minedu.fi/en/ policies-and-development-general-education. Accessed 28 Oct 2020

Nielsen, J. L., \& Andreasen, L. B. (2013). Educational designs supporting student engagement through networked project studies. In L. A. Wankel \& P. Blessinger (Eds.), Increasing student engagement and retention using mobile applications: Smartphones, Skype and texting technologies (pp. 19-46). Emerald Group Publishing.

Norwich, B. (2013). Addressing tensions and dilemmas in inclusive education. Living with uncertainty. Abingdon: Routledge.

Pakarinen, E., Lerkkanen, M. K., Poikkeus, A. M., Kiuru, N., Siekkinen, M., Rasku-Puttonen, H., \& Nurmi, J. E. (2010). A validation of the classroom assessment scoring system in Finnish kindergartens. Early Education and Development, 21, 95-124.

Pianta, R. C., La Paro, K. M., \& Hamre, B. K. (2008). Classroom assessment scoring system (CLASS) manual, pre-K. Baltimore: Paul H. Brookes Publishing.

Qvortrup, A., \& Qvortrup, L. (2018). Inclusion: Dimensions of inclusion in education. International Journal of Inclusive Education, 22(7), 803-817. https://doi.org/10.108 0/13603116.2017.1412506. 
Radencich, M. C., \& McKay, L. J. (1995). Flexible grouping for literacy in the elementary grades. Boston: Allyn and Bacon.

Ralabate, P. K. (2016). Your UDL lesson planner. The step-by-step guide for teaching all learners. Baltimore: Paul H. Brookes Publishing.

Rodgers, J. L., \& Nicewander, W. A. (1988). Thirteen ways to look at the correlation coefficient. The American Statistician, 42(1), 59-66. https://doi.org/10.1080/00031305.1988.10475524.

Rose, D. (2014). Re-envisioning education through UDL. In A. Meyer, D. H. Rose, \& D. Gordon (Eds.), Universal design for learning. Theory and practice (pp. 1-20). Wakefield: CAST.

Rose, D. H., Gravel, J. G., \& Gordon, D. T. (2014). Universal design for learning. In L. Florian (Ed.), The Sage handbook of special education (pp. 475-489). London: Sage.

Rouse, M. (2010). Reforming initial teacher education: A necessary but not sufficient condition for developing inclusive practice. In C. Forlin (Ed.), Teacher education for inclusion (pp. 48-55). New York: Routledge.

Ryan, R. M., \& Deci, E. L. (2016). Self-determination theory. Basic psychological needs in motivation, development, and wellness. New York: The Guilford Press.

Sahlberg, P. (2010). The secret to Finland's success: Educating teachers. Stanford Center for Opportunity Policy in Education, 2, 1-8. http://edpolicy.stanford.edu/sites/default/files/publications/secret-finland's-success-educating-teachers.pdf. Accessed 5 June 2020.

Shani, M., \& Hebel, O. (2016). Educating towards inclusive education: Assessing a teachertraining program for working with pupils with special educational needs and disabilities (SEND) enrolled in general education schools. International Journal of Special Education, 31(3), 1-23.

Shulman, L. (1987). Knowledge and teaching: Foundations of the new reform. Harvard Educational Review, 57, 1-23.

Slee, R. (2014). Inclusive schooling as an apprenticeship in democracy? In L. Florian (Ed.), The Sage handbook of special education (pp. 217-229). London: Sage.

Spratt, J., \& Florian, L. (2015). Inclusive pedagogy: From learning to action. Supporting each individual in the context of "everybody". Teaching and Teacher Education. An International Journal of Research and Studies, 49, 89-96. https://doi.org/10.1016/j.tate.2015.03.006.

Tjernberg, C., \& Heimdahl Mattson, E. (2014). Inclusion in practice: A matter of school culture. European Journal of Special Needs Education, 29(2), 247-256. https://doi.org/10.108 0/08856257.2014.891336.

Tomlinson, C. A. (1999). The differentiated classroom: Responding to the needs of all learners. Alexandria: Association for Supervision and Curriculum Development.

van Driel, J., Beijaard, D., \& Verloop, N. (2001). Professional development and reform in science education: The role of teachers' practical knowledge. Journal of Research in Science Teaching, 38(2), 137-158. https://doi.org/10.1016/j.tate.2013.09.001.

Vygotsky, L. (1978). Mind in society: The development of higher psychological processes. Cambridge, MA: Harvard University Press.

Watkins, A., \& Donnelly, V. (2012). Teacher education for inclusion in Europe: Challenges and opportunities. In C. Forlin (Ed.), Future directions for inclusive teacher education. An international perspective (pp. 192-202). Abingdon: Routledge.

Yin, R. K. (2014). Case study research. Design and methods (5th ed.). Thousand Oaks: Sage. 
Open Access This chapter is licensed under the terms of the Creative Commons Attribution 4.0 International License (http://creativecommons.org/licenses/by/4.0/), which permits use, sharing, adaptation, distribution and reproduction in any medium or format, as long as you give appropriate credit to the original author(s) and the source, provide a link to the Creative Commons license and indicate if changes were made.

The images or other third party material in this chapter are included in the chapter's Creative Commons license, unless indicated otherwise in a credit line to the material. If material is not included in the chapter's Creative Commons license and your intended use is not permitted by statutory regulation or exceeds the permitted use, you will need to obtain permission directly from the copyright holder. 